\title{
Older Human B Cells and Antibodies
}

\author{
Deborah K. Dunn-Walters and Joselli Silva O'Hare
}

\begin{abstract}
$\mathrm{B}$ cells have a number of different roles in the immune response. Their excellent antigen presentation potential can contribute to the activation of other cells of the immune system, and evidence is emerging that specialized subsets of these cells, that may be increased with age, can influence the cell-mediated immune system in antitumor responses. They can also regulate immune responses, to avoid autoreactivity and excessive inflammation. Deficiencies in regulatory B cells may be beneficial in cancer but will only exacerbate the inflammatory environment that is a hallmark of aging. The B cell role as antibody producers is particularly important, since antibodies perform numerous different functions in different environments. Although studying tissue responses in humans is not as easy as in mice, we do know that certain classes of antibodies are more suited to protecting the mucosal tissues (IgA) or responding to $\mathrm{T}$-independent bacterial polysaccharide antigens $\left(\mathrm{IgG}_{2}\right)$ so we can make some inference with respect to tissue-specific immunity from a study of peripheral blood. We can also make inferences about changes in B cell development with age by looking at the repertoire of different $\mathrm{B}$ cell populations to see how age affects the selection events that would normally occur to avoid autoreactivity, or increase specificity, to antigen.
\end{abstract}

D.K. Dunn-Walters $(\bowtie)$

Faculty of Health and Medical Sciences, University of Surrey, Guildford, Surrey, UK

Faculty of Life Sciences \& Medicine, King's College London, London, UK

e-mail: d.dunn-walters@surrey.ac.uk

J.S. O'Hare

Immunology, University of Surrey, Guildford, UK

e-mail: j.silva-o'hare@surrey.ac.uk 


\section{Keywords}

Tolerance $\cdot \mathrm{B}$ cell repertoire $\cdot$ Autoantibodies $\bullet$ Immunoglobulin genes $\bullet$ Agerelated B cells $\bullet$ Aging $\bullet$ Antibody class switching $\bullet$ Affinity maturation $\bullet$ Regulatory B cells $\bullet$ Humoral immunity

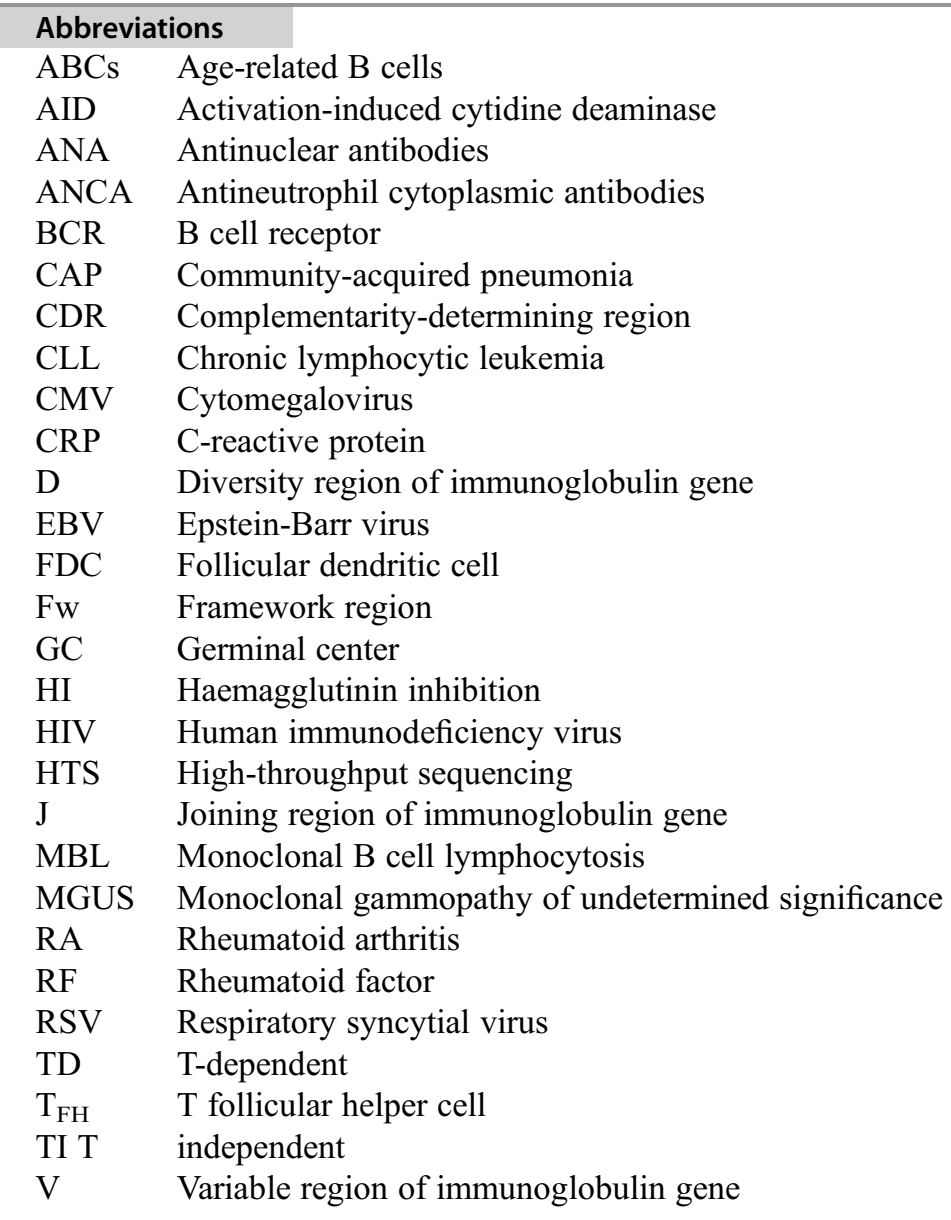

\section{Contents}

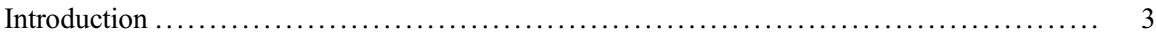

Role of B Cells in Age-Associated Susceptibility to Infection ....................... 3

B Cell Role in Protection from Infection ....................................... 4

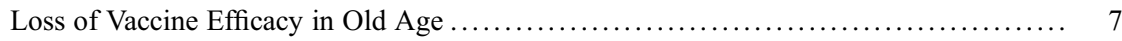

Age-Associated Inflammation and Loss of B Cell Tolerance ......................... 9

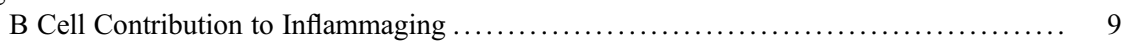

Autoantibodies in Older People ............................................... 9

Functional Subclasses of B Cells and Age-Related Changes ......................... 11

CD27- Memory B Cells ................................................. 11 
Age-Related B Cells ............................................... 12

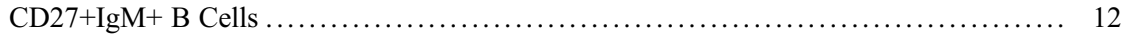

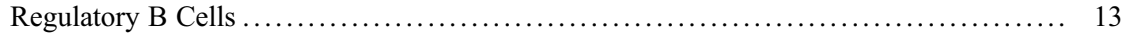

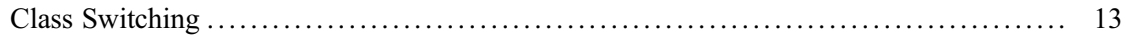

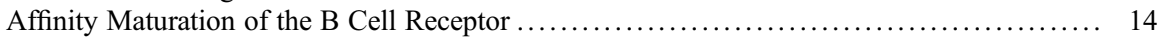

Germinal Center Environment $\ldots \ldots \ldots \ldots \ldots \ldots \ldots \ldots \ldots \ldots \ldots \ldots \ldots \ldots \ldots \ldots \ldots \ldots \ldots \ldots$

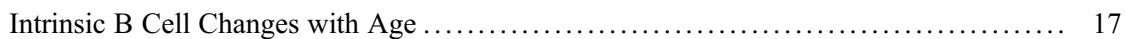

The Older B Cell Receptor Repertoire $\ldots \ldots \ldots \ldots \ldots \ldots \ldots \ldots \ldots \ldots \ldots \ldots \ldots \ldots \ldots \ldots \ldots \ldots . \ldots \ldots$

Dysregulation of the Repertoire in Older People $\ldots \ldots \ldots \ldots \ldots \ldots \ldots \ldots \ldots \ldots \ldots \ldots \ldots \ldots . \ldots$

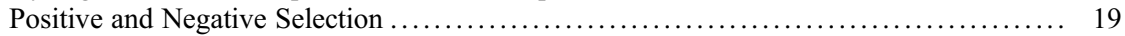

Interaction of Humoral Immunity with Other Systems $\ldots \ldots \ldots \ldots \ldots \ldots \ldots \ldots \ldots \ldots \ldots \ldots \ldots 20$

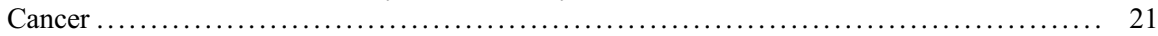

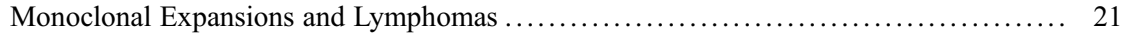

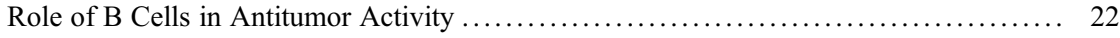

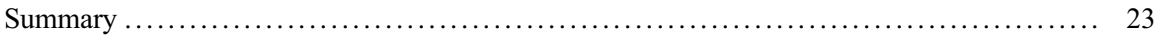

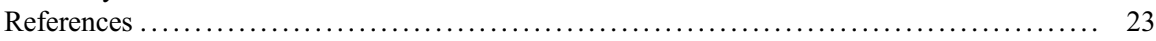

\section{Introduction}

It has been well established that the efficiency of the immune system declines with increasing age. Immunosenescence causes increased susceptibility to infectious diseases, and infection is, in fact, the third leading cause of mortality in people aged 65 and over (Albright and Albright 2003). Even in cases where mortality is not an issue, reducing morbidity of infection in older people is an urgent need in order to improve the health of the older generation. As is clearly apparent from the other chapters of this book, there are many components of the immune system that can change with age and are crucial to maintaining an effective immune system. In this chapter, we address current knowledge on age-related changes in the humoral immune system and how this contributes to the immune frailty of the older person.

\section{Role of B Cells in Age-Associated Susceptibility to Infection}

The humoral immune system interacts with the other immune components in a number of different ways. The terminal differentiation point of B cell development is the plasma cell, which produces large quantities of antibody. In more recent years, it has become apparent that there are other critical functions of B cells in activating or suppressing immune responses. They can be important as modulators of inflammation (Arnaboldi et al. 2005; Maglione et al. 2007), as regulators of the immune response (Mauri and Menon 2015), and as antigen-presenting cells and activators of T cells (Linton et al. 2000; Crawford et al. 2006; Lund et al. 2006). An overview of B cell development is shown in Fig. 1. 


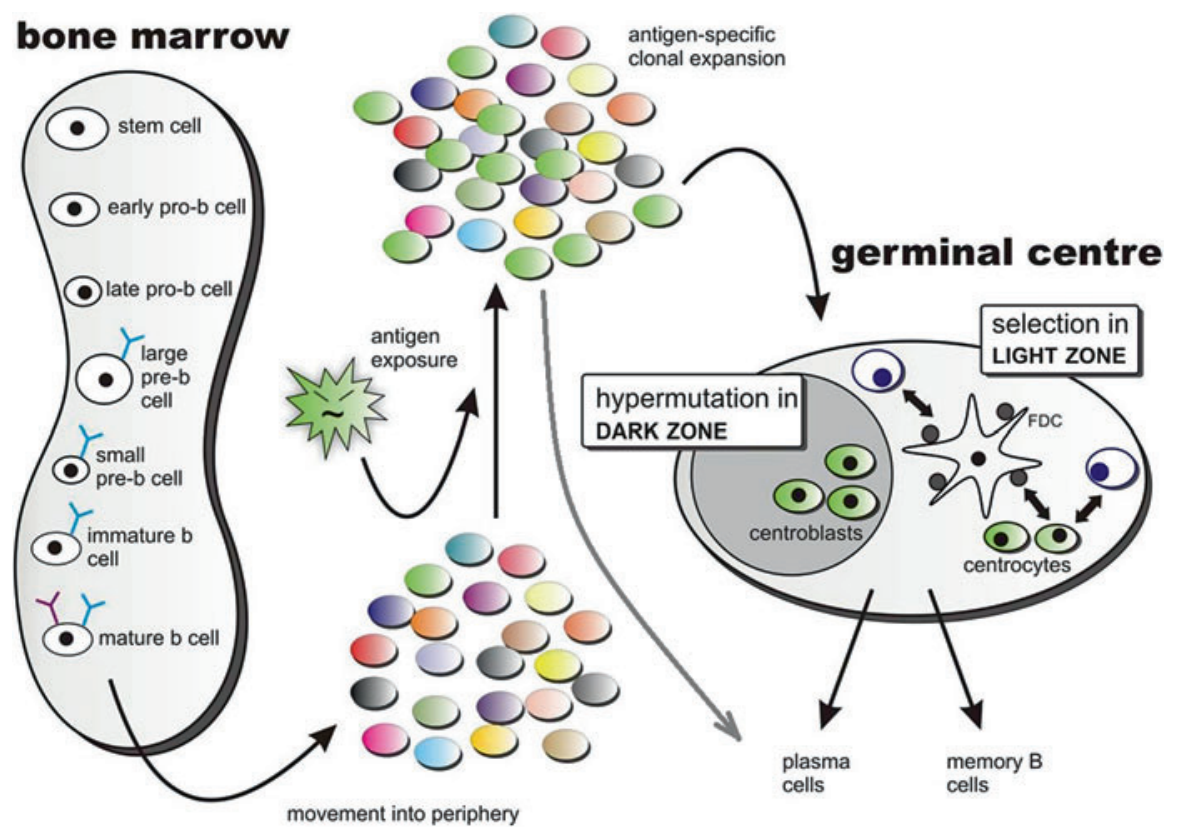

Fig. $1 \mathrm{~B}$ cell development. The humoral immune response is mediated by antibodies produced from plasma cells. These plasma cells are the end point in B cell development, which is characterized by (a) generation of a huge diversity of different B cells, each carrying a different antibody gene in the bone marrow and (b) selection processes using the affinity of the membrane-bound form of the antibody (the B cell receptor) for its antigen as the selection criteria. Diversity is generated by a process of gene rearrangement early on in the development of the cell, in the bone marrow prior to antigen encounter. T-dependent activation of B cells occurs via the germinal center. Innate B cell activation by T-independent antigens can also occur. Selection processes shape the repertoire. In the bone marrow, B cells are selected for survival, or not, on the basis of their antibody recognition - to eliminate inappropriate self-reactivity and encourage reactivity with foreign pathogens. In the germinal center, there is a mutation step, and the resultant B cells carrying improved antibodies are selected; this serves to increase the affinity of the antibody for the relevant antigen. Both generation of diversity and selection of antibody are complex processes that are crucial for an effective humoral immune system. A clear understanding of these processes, and how they are affected with age, is needed in order to comprehend the etiology of age-related inflammatory and infectious disease

\section{B Cell Role in Protection from Infection}

In the primary $\mathrm{B}$ cell response, antibodies that recognize pathogen, although not necessarily with high affinity, are rapidly produced. They may include the so-called "polyspecific" antibodies, which have the ability to bind to multiple antigens (Meffre and Wardemann 2008; Mouquet et al. 2010; Scheid et al. 2011). The first antibodies are of the IgM class and are crucial for opsonizing pathogens, inducing phagocytosis, and activating the complement cascade. These antibody functions, and the rapidity of this primary response, have been shown to play a vital role in protection from extracellular bacterial pathogens (Brown et al. 2002). 
Table 1 Pathogens found frequently in elderly subjects with respiratory, gastrointestinal, and urinary tract infections

\begin{tabular}{|c|c|c|}
\hline Organ system & $\begin{array}{l}\text { Pathogen found } \\
\text { frequently }\end{array}$ & B cell role in immune response to pathogen \\
\hline \multirow{8}{*}{$\begin{array}{l}\text { Respiratory } \\
\text { tract }\end{array}$} & S. pneumoniae & B cells crucial for TI response (Barrett and Ayoub 1986) \\
\hline & H. influenza & Mucosal IgA protects (Pichichero et al. 1981) \\
\hline & L. pneumophila & B cells required for opsonization (Brieland et al. 1996) \\
\hline & C. pneumonia & Neutralization by antibody (Peterson et al. 1998) \\
\hline & Rhinoviruses & \multirow{4}{*}{$\begin{array}{l}\text { Antibody-mediated neutralization (Smith et al. 1996; } \\
\text { Zhong et al. 2005) }\end{array}$} \\
\hline & Coronaviruses & \\
\hline & Influenza & \\
\hline & $\begin{array}{l}\text { Respiratory } \\
\text { syncytial Virus }\end{array}$ & \\
\hline \multirow[t]{4}{*}{ Urinary tract } & E. coli & $\begin{array}{l}\text { IgA secretion inhibits bacterial attachment (Trinchieri } \\
\text { et al. 1990; Kantele et al. 2003) }\end{array}$ \\
\hline & P. klebsiella & $\begin{array}{l}\text { IgM and IgA aids protection (Lepper et al. 2003; Deo } \\
\text { et al. 2004) }\end{array}$ \\
\hline & P. aeruginosa & Opsonization (Mueller-Ortiz et al. 2004) \\
\hline & Enterococci & $\begin{array}{l}\text { Antibody effective in the presence of complement (Harvey } \\
\text { et al. 1992) }\end{array}$ \\
\hline \multirow[t]{2}{*}{ Gastrointestinal } & E. coli & Mucosal IgA protects \\
\hline & C. difficile & $\begin{array}{l}\text { Strong antibody and memory B cells required to protect } \\
\text { (Monaghan et al. 2013) }\end{array}$ \\
\hline
\end{tabular}

T-independent responses, in general, are particularly important in protection against bacterial pathogens, where the external antigens of the pathogen are nonprotein in nature. Antibodies afford protection against viral infection by neutralizing virus particles, binding and blocking key molecules involved in cellular infection. Similarly, they can also neutralize toxins. Later T-dependent affinity maturation of B cells in an immune response is slower but results in the generation of more highly specific antibodies, often of a different class.

The elderly are susceptible to infections by a wide variety of pathogens, all of which involve B cells and antibodies in the normal course of the immune response (Table 1). The lungs are, in common with other mucosal surfaces of the gastrointestinal and genitourinary tracts, particularly vulnerable to infection by virtue of their exposure to the environment. As is illustrated in Table 1, pulmonary infections are common in older people. The elderly are usually the first to be affected by annual epidemics of respiratory infections and frequently suffer the worst clinically. Mortality figures attributable to influenza and pneumonia are confused by the fact that influenza is very often followed by a secondary infection - most notably by Streptococcus pneumoniae (Brinkhof et al. 2006; van der Sluijs et al. 2004; Seki et al. 2004). Resolution of a first infection can leave a person susceptible to a secondary bacterial infection, and this may be of particular concern in older people (Dunn-Walters and Ademokun 2010; Ademokun et al. 2011). It has been reported that $90 \%$ of all pneumonia and influenza deaths and $88 \%$ of respiratory syncytial virus (RSV)-associated deaths occur in those aged over 65 years (Thompson et al. 
2003; Matias et al. 2014). In the oldest old (85 years and over), there was a 32-fold increased chance of mortality from influenza or influenza-associated pneumonia compared with those aged 65-69 years (Thompson et al. 2003). A prospective study, following 608 healthy elderly, showed that approximately twice as many people had RSV infection than did influenza A infection, and in a period of 2 years, $13 \%$ of these patients contracted either influenza or RSV (Falsey et al. 2005). The predicted probability for Older patients with community-acquired pneumonia (CAP) to enter hospital within 28 days of Contracting CAP is $86 \%$ (Millett et al. 2015). There is also an increased incidence of pneumococcal septicemia in old people associated with S. pneumoniae infection (McIntosh et al. 2005; Weil-Olivier et al. 2012).

It is known that specific antibodies generated during a T-dependent B cell response are crucial for protection against influenza. Ineffective influenza-specific antibody, as assessed by the hemagglutination inhibition (HI) test, is associated with lowered protection from the disease (Goodeve et al. 1983). It has been said that an age-related decrease in influenza protection can be solely accounted for by the reduced $\mathrm{T}$ cell help available in the diminished elderly $\mathrm{T}$ cell repertoire. However, this does not take into account the fact that the CD4+ T cells themselves may rely on fully functioning B cells for their activation (Rivera et al. 2001; Crawford et al. 2006).

In other areas of humoral immunity, the B cells are even less reliant on T cells for help. Pneumonia is a bacterial infection, caused by a number of different organisms (e.g., Streptococcus pneumoniae, Staphylococcus aureus, Streptococcus pyogenes) although $S$. pneumoniae is the major cause (AlonsoDeVelasco et al. 1995; Birch and Gowardman 2000; Hageman et al. 2006). Immunity against S. pneumoniae is particularly reliant on a healthy B cell population, since the antigenic portion of S. pneumoniae is a capsular polysaccharide and a T-independent type II (TI-II) antigen. Unlike a T-dependent B cell response, where the maturation of the B cell antibody relies on $\mathrm{T}$ cell help and therefore any failure to respond could be attributed to a failure of $\mathrm{T}$ cells, this response is independent of direct $\mathrm{T}$ cell help. Therefore a failure to protect against $S$. pneumoniae is more likely to be a failure ascribable to deficits in the B cells themselves.

In children a reduced pneumococcal response can be explained by a lack of marginal zone B cells in the spleen, where the main TI-II responding B cells are thought to reside. However, older people appear to have a fully functioning splenic marginal zone (Banerjee et al. 2000). CD27+IgM+ B cells are thought to be the recirculating equivalent of the splenic marginal zone, provide protection from S. pneumoniae (Kruetzmann et al. 2003), and show age-related changes (see below) which may account for a reduced response to TI-II antigens. Removal of IgM from human serum diminishes phagocytosis of $S$. pneumoniae in in vitro assays (Park and Nahm 2011), also indicating that IgM has a crucial role in protection from pneumococcal disease. Complementary to this we discovered that, although polysaccharide-specific IgG was equivalent in old and young patients after vaccination, the production of specific $\operatorname{IgM}$ and $\operatorname{IgA}$ antibodies was significantly diminished (Ademokun et al. 2011). 
Although pulmonary infections of the elderly are the most notable, by virtue of the fact that they cause the most mortality, there are also significant increases in morbidity and mortality from other infections. Bacterial infections of the skin, urinary tract, soft tissue and gastrointestinal tract are all increased with age (Albright and Albright 2003) and infections from organisms such as Clostridium difficile and Candida albicans seem almost exclusive to the older age groups (Fig. 2). Sepsis is a particular problem in older people, and the severity of disease has been shown to correlate with serum levels of IgM in the elderly (Suzuki et al. 2016).

\section{Loss of Vaccine Efficacy in Old Age}

Vaccines are an extremely important tool in preventing deaths from infection and, since they are routinely administered as part of a normal health-care routine, are the main source of data on immune responses in man. It has been consistently shown that the effectiveness of vaccines is severely diminished in older people. Since specific antibody production is often used as a correlate of protection, vaccine studies are a useful way of observing the humoral immune response. An agerelated reduction in specific antibody production occurs in response to many vaccines, including hepatitis B (Fourati et al. 2016), pneumonia (Simberkoff et al. 1986; Koivula et al. 1997; Örtqvist et al. 1998, 2007; Rubins and Janoff 2001), tetanus, diphtheria and tick-borne encephalitis (Hainz et al. 2005; Weinberger et al. 2013). The most commonly studied vaccine is that against influenza. The cellular response, i.e., $\mathrm{T}$ cells and release of cytokines, macrophages, and natural killer cells, is decreased with age, and the IgG antibody titer is significantly lower (Goronzy and Weyand 2013; McElhaney et al. 2016). While vaccination of older people against influenza is widely accepted as a valid health strategy to reduce disease incidence (Odelin et al. 2003; Keitel et al. 2006; Maciosek et al. 2006), disease mortality may not be affected (Simonsen et al. 2005; Rizzo et al. 2006). In agreement with previous studies, we have shown that older people fail to develop protective Haemagglutinin inhibition (HI) titers following vaccination (Ademokun et al. 2011; Reber et al. 2015). Recent studies have investigated different vaccination regimes in an effort to improve protection in the elderly. There is some evidence that boosting within 12 months of vaccination improves antibody responses and reduces innate responses (Kannan et al. 2015). Successive vaccination can improve the older immune response to levels shown by younger adults (Höpping et al. 2016). In the case of influenza, the response that is being studied is that of a recall response and may be complicated by the existence of slightly cross-reactive antibodies formed against previous strains of influenza. A study of vaccine responses against diseases that are not endemic in the country of origin can circumvent this. Some travel vaccines, such as hepatitis A, also show a reduced specific antibody response (Genton et al. 2006), while others such as yellow fever seem to show an undiminished antibody response but the response takes longer (Roukens et al. 2011), and there is an increased risk of adverse events in older people (Monath et al. 2005; Roukens et al. 2011; Thomas et al. 2012). 


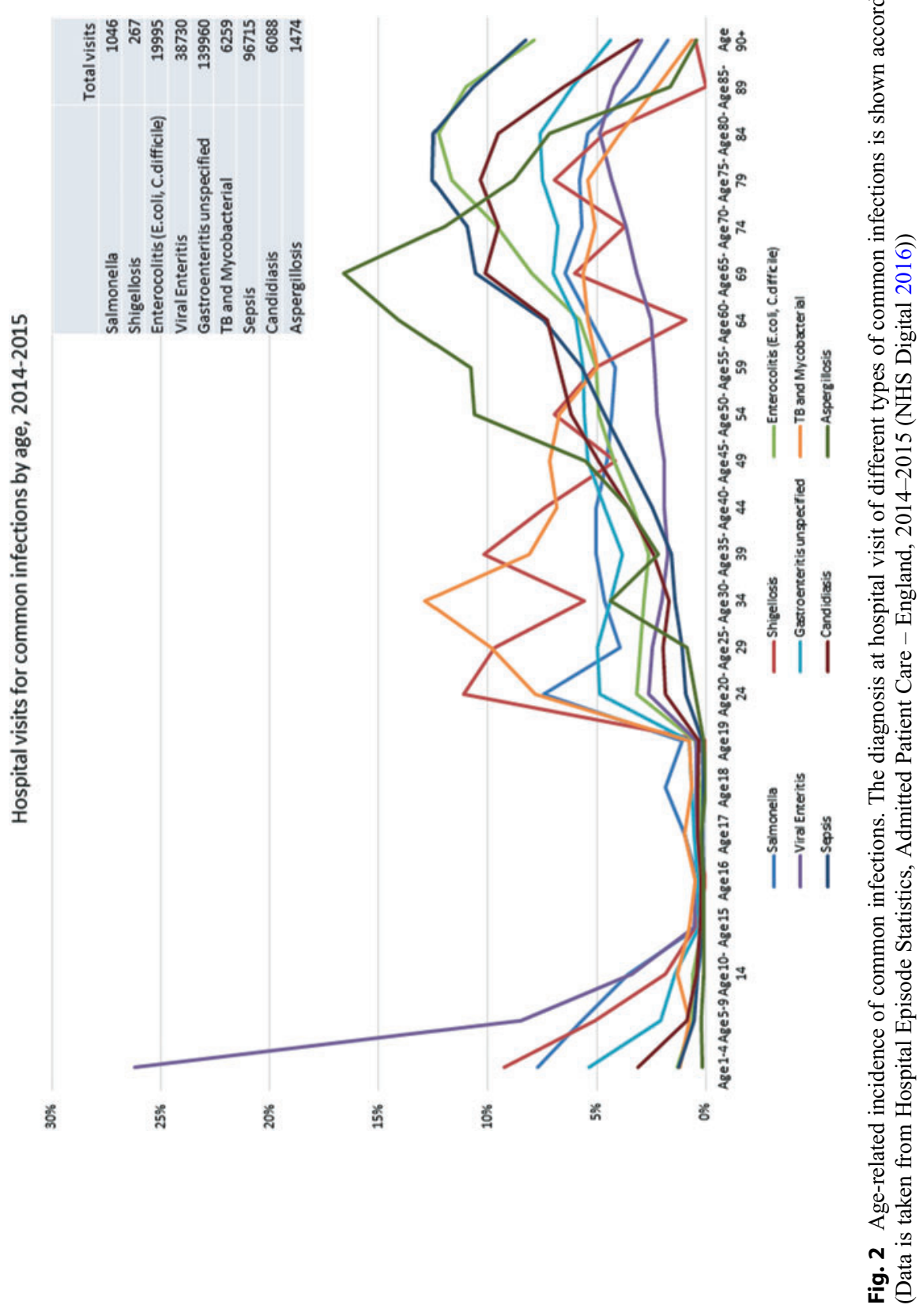




\section{Age-Associated Inflammation and Loss of B Cell Tolerance}

Aging is associated with an increased level of inflammatory markers such that this phenomenon which is sometimes referred to as "inflammaging." The most consistent data associates age and increased TNF $\alpha$ and IL6 cytokine levels in the serum; CRP is often also measured. IL-6 and CRP levels have been shown to predict physical and mental frailty and mortality risk (Puzianowska-Kuźnicka et al. 2016). Pre-existing inflammation can result in reduced responses to challenge; high levels of inflammatory response transcripts in human blood inversely correlate with responses to hepatitis B vaccine (Fourati et al. 2016). Evidence from mice suggests that the inflammatory environment causes a reduction in hematopoiesis in the bone marrow (Ratliff et al. 2013), which in itself is a major risk factor for frailty in the elderly. In addition, since inflammation is implicated in the pathogenesis in the majority of age-related diseases, and the immune system is the primary causative candidate, there is a great deal of interest in understanding the contribution of immunity to age-related inflammation. Similarly, aging is associated with an increase of autoreactive antibodies (Ademokun et al. 2011), and the significance of this is not completely understood.

\section{B Cell Contribution to Inflammaging}

Inflammatory cytokines can be secreted by many different cells, and it is worth noting that it is not only immune cells that can secrete inflammatory cytokines. Particularly with regard to age-related changes, the senescence-associated secretory phenotype of senescent cells must also be considered (Campisi et al. 2011). In the overall environment, with contributions from many other cells, it is not clear whether B cells make a significant contribution to the overall inflammatory milieu, although evidence is gradually emerging to show that their cytokine profile and responses are changed so they do contribute at some level. Older memory B cells have been shown to secrete higher levels of TNF $\alpha$. TNF $\alpha$ in turn is negatively correlated with the overall immune response and, in particular, with a lower level of activity of the enzyme AID in B cells that is critical for the affinity maturation response (Frasca and Blomberg 2014). An increased production of IL6 has also been shown in older B cells (Bancos and Phipps 2010) and a reduction of IL6-expressing B cells in the clinic has been shown to ameliorate autoimmune disease (Barr et al. 2012) so the production of inflammatory cytokines from older B cells warrants further study.

\section{Autoantibodies in Older People}

There is a well-documented shift toward self-reactive antibody production with age, although generally not associated with autoimmune disease per se. Rheumatoid arthritis (RA) is an age-related inflammatory autoimmune disorder, and the increase in rheumatoid factor (RF) with age tempts one to assume a causal link. However, the 
increase in RF occurs regardless of whether the subject has RA or not (AndersenRanberg et al. 2004), and the presence of another autoantibody, anti-cyclic citrullinated peptide is associated with a higher risk of RA. This antibody is likely a result of environmental factors - specifically with smoking (Michou et al. 2008). The successful use of therapies such as rituximab, which utilize an anti-CD20 monoclonal antibody to ablate peripheral $\mathrm{B}$ cells, is ample evidence that $\mathrm{B}$ cells play an important part in the disease process of RA, but their role as antigenpresenting cells, activating $\mathrm{T}$ cells, and producers of cytokines may be more prominent than as autoantibody producers (Bugatti et al. 2014). A further complication in understanding the role of $\mathrm{B}$ cells in RA is their role as regulators, as outlined below. Another age-related autoimmune disease is ANCA-associated vasculitis, with a peak incidence at age 65-74 in the UK (Watts et al. 2000). The disease is characterized by antineutrophil cytoplasmic antibodies (ANCA), of which the two most common targets are myeloperoxidase (MPO-ANCA) and proteinase 3 (PR3-ANCA). In this instance, the role of the autoantibodies seems to be clear, in that they inappropriately activate neutrophils leading to systemic inflammation affecting joints, lungs, kidneys, and other tissues. The association with older age implies that B cell tolerance mechanisms with respect to ANCA are more likely to fail in the elderly.

However, as mentioned above, many autoreactive antibodies are increased in aging but are not pathogenic. Antinuclear antibodies (ANA) have consistently been found to be increased in the old (over 65) in the absence of disease; the Swedish longitudinal NONA immune study (Nilsson et al. 2006) showed significantly higher ANA levels in the oldest old (86-95 years) but found there to be no association nor any correlation to other immune risk factors (e.g., CD4/CD8 T cell ratio, CMV seropositivity). These findings are echoed by a Finnish study, where ANA positivity at the age of 90 did not show any correlation with survival or with the levels of serum markers of inflammation (Hurme et al. 2007). We saw a significant increase in IgG ANA autoantibodies with age which was unaffected by vaccination, so unlikely to be caused by bystander activation of polyspecific antibodies in a response (Ademokun et al. 2011). Other age-related increases occur in anti-ssDNA antibodies (Manoussakis et al. 1987; Xavier et al. 1995; Ioannidis et al. 2003), cardiolipin, and dsDNA.

Understanding the increase of autoantibodies without autoimmune disease becomes easier if we stop thinking about an antibody as being exclusively specific for one antigen - as in the lock and key hypothesis. Rather, we believe that all antibodies will have a certain amount of polyreactivity, perhaps particularly in the case of naïve $B$ cells or T-independent responders such as $\operatorname{IgG}_{2}$ B cells or $\operatorname{IgM}$ memory cells. The relative ability to bind self-antigen versus non self-antigen will determine whether the antibody survives the tolerance mechanisms, and highly specific antibody can be generated later in a response - through affinity maturation in the germinal center T-dependent process. With this view in mind, then the increase in nonpathogenic autoantibodies in aging could be explained by a relaxation of the tolerance mechanisms, not causative of autoimmune disease in themselves, but perhaps a contributory factor toward increased incidence of disease such as RA or vasculitis. Data from our lab shows that there are immunoglobulin sequence 
characteristics that are removed from the repertoire in central tolerance, and the extent to which these are removed decreases with age (Martin et al. 2016).

\section{Functional Subclasses of B Cells and Age-Related Changes}

Most studies will agree that immune senescence does not involve a change in total B cell numbers, as assessed by the pan B cell marker CD19 (Ademokun et al. 2010; Melzer et al. 2015). We now know that there are many functions of B cells in addition to their role as antibody producers, and discovery of phenotypic markers to define functional subsets is an ongoing process. Most work in human is performed in blood, for obvious reasons, but we should not forget that the B cell microenvironment within tissues is extremely important and may result in a different cellular landscape than in PBMCs. Indeed, the fact that mouse studies are mostly from splenic B cells and humans are mostly PBMCs may confound attempts at extrapolation from mouse to human studies. In many instances, the starting point for distinction between human subsets is the expression of surface markers CD19 (pan $\mathrm{B}$ cell), IgD, and CD27. IgD is present on all mature B cells that have not been activated by exogenous antigen and also on a population of "IgM memory cells". CD27 is an activation marker on B cells and is present on most, but not all, memory cells. In this instance, B cell memory is generally confirmed by class switching and/or the presence of mutations in the Ig gene. Markers CD24 and CD38 are also often used to distinguish functional populations of cells. Comparing populations defined by $\operatorname{IgD} / \mathrm{CD} 27$ with those defined by $\mathrm{CD} 24 / \mathrm{CD} 38$ is broadly possible, although there are some cells showing exception which serves to illustrate the heterogeneity of many of these populations (Boyd et al. 2013).

\section{CD27- Memory B Cells}

There is a population of B cells that has lost $\operatorname{IgD}$, has mutations in the Ig genes, and includes class-switched antibodies as well as a small population of IgM-only antibodies. All these are the hallmark signs of memory B cells, but the activation marker CD27 is not present on the surface (Wu et al. 2011). These cells are increased in aging (Bulati et al. 2011), as well as in autoimmune disease and chronic viral infections such as HIV (Wei et al. 2007; Moir et al. 2008), and have been associated with frailty (Lu et al. 2016). It has been suggested that they are exhausted B cells, which have been a long time in activation and can no longer continue the response. However, the level of mutation in the Ig genes of these cells is generally lower than in the CD27+ cells (Wu et al. 2011), so it is difficult to argue that they have been activated for longer time. It has also been suggested that this population of cells contains tissue-like memory B cells that are activated by T-independent mechanisms as they are present in CD40-deficient individuals and therefore cannot receive T cell help to mature (Zelm et al. 2014). We can see evidence of related clones between the CD27- and CD27+ populations, but the lineage analysis does not show that one is 
consistently derived from the other (Wu et al. 2011). Coupled with our data that shows some CDR3 character differences between the populations (Wu et al. 2011), we are inclined to think of this population of cells as containing a "sin bin" for potentially autoreactive B cells that do not receive enough accessory cell help to allow them to continue the activation and maturation process. This does not exclude the possibility that $\mathrm{T}$ cell-independent responders, and potentially other types of cells, are included here. If this is the case, then an increase in this population with age implies a decrease in $\mathrm{T}$ cell help which allows potentially autoreactive antibodies to progress and/or loss of early stage tolerance mechanisms allowing more autoreactive $\mathrm{B}$ cells into the peripheral milieu. As with all these broadly gated populations of cells, it is likely that the population is heterogeneous, and so some detail of individual subset types may be lost in the averaging process when the population as a whole is measured.

\section{Age-Related B Cells}

There is a population of cells in mice identified as "age-related B cells" (ABCs) that accumulate with age and have very specific functional characteristics, including those predisposing toward autoimmune activation (Naradikian et al. 2016). ABCs are antigen presenters with high levels of CD86 and MHC II (Rubtsova et al. 2015). Work to place the human equivalent of these cells within the conventional human phenotyping of subsets is still ongoing. Since the CD27- memory subset increases with age and contains class-switched cells with hypermutation in their genes, then it is possible that that $\mathrm{ABCs}$ will fall in this category, particularly with the associations with infection and autoimmunity that have been made for both $\mathrm{ABCs}$ and human CD27- memory cells (Wei et al. 2007; Moir et al. 2008). The CD27- memory cells may be a tissue-related memory population with surface markers indicating trafficking to tissues including the mucosa (Bulati et al. 2014; Berkowska et al. 2015). The relationship of ABCs to the 4-1BBL+ B cells that have been identified by Lee-Chang et al. (2014) to be increased with age in human, macaque, and mice is not clear. 4-1BBL+cells also have increased CD86 and MHC, with high levels of CD40. The human 4-1BBL+ population appears to be divided into two groups with respect to CD27 positivity (Lee-Chang et al. 2014). More detailed phenotypical analysis of these populations is needed to reconcile the contradictions and place the $\mathrm{ABCs}$ in the context of other functional populations.

\section{CD27+lgM+ B Cells}

These cells are thought to be the recirculating equivalent of splenic marginal zone B cells, retaining $\operatorname{IgM}$ and $\operatorname{IgD}$ but also with mutations in their Ig genes and expressing CD27 on their surface (Dunn-Walters et al. 1995; Capolunghi et al. 2013; Bagnara et al. 2015). They are important in T-independent responses against antigens such as pneumococcal polysaccharides and therefore crucial in protection 
against bacteria (Shi et al. 2005). This population of cells decreases with age (Martin et al. 2015), which has serious implications for antibacterial immunity. The population itself is extremely heterogeneous, containing possible T-dependent relatives of switched memory cells, CD5+ B1 B cell equivalents (Rothstein and Quach 2015), and cells that respond to activation by neutrophils (Puga et al. 2011). We have shown that cells vary by the relative quantities of $\operatorname{IgM}$ and $\operatorname{IgD}$ on the surface within this population. The proportions of these different $\operatorname{IgM}^{\text {hi }} \operatorname{IgD}^{\text {lo }}$ versus $\operatorname{IgM}^{\mathrm{lo}} \operatorname{IgD}{ }^{\text {hi }}$ populations change with age and likely reflect a change in the proportions of different functional subsets (Martin et al. 2015).

\section{Regulatory B Cells}

B regs are potent suppressors of immune responses, both by secretion of IL10 and by other contact-dependent mechanisms that have yet to be fully elucidated. Although a phenotype for B regs has not yet been determined, and IL10 alone does not appear to be an identifier, it seems that B regs are mostly found in the transitional B cell population (Mauri and Menon 2015). This is the population identified by $\mathrm{CD} 24{ }^{\mathrm{hi}} \mathrm{CD} 38^{\mathrm{hi}} \mathrm{CD} 27^{-}$or by $\mathrm{IgD}^{+} \mathrm{CD} 27^{-} \mathrm{CD} 10^{\text {hi }}$. This population of cells has been shown to decrease with age (Duggal et al. 2013; van der Geest et al. 2016), which will have deleterious consequences for control of inflammatory responses. Other B cell subsets can produce the suppressive cytokine IL10, in particular the IgM memory population defined by $\operatorname{IgD}^{+} \mathrm{CD} 27^{+}$. If, it is the IL10 rather than the contact-dependent mechanism of suppression that is changed with age (Duggal et al. 2013), then the capacity of other B cells to produce IL10 is also important. A decrease in IgM memory cells with age, as mentioned above, will likely also result in reduced IL10 production capacity. Indeed the studies of van der (Geest et al. 2016) indicate that IL10 production from all B cells decreases with age, while the ability to produce the inflammatory cytokine $\mathrm{TNF} \alpha$ is unaffected. Moreover there may be differential effects on different types of autoantibodies, since ANA correlated with IL10 production ability but RF did not (van der Geest et al. 2016).

\section{Class Switching}

A general increase in CD27+ memory cells has been reported with age (Macallan et al. 2005; Colonna-Romano et al. 2006). Memory cells are often described as "class switched" with no further distinction. IgG is by far the most common antibody in circulation and therefore the most prevalent in the literature. However, in recent years, evidence is emerging to indicate that different classes and subclasses of antibody have critical roles in the immune response. IgA antibodies are thought of as mucosal antibodies, and the huge area of exposure to exogenous antigens at mucosal surfaces certainly requires specialized and efficient protection. The physiology of the gut undergoes significant changes with age, and much more work is required to understand the complex relationship between gut physiology, microbiota, 
and the mucosal immune system in aging (Mabbott et al. 2015). The character of the germinal center in Peyer's patches changes with age, with indications of less specific antibody selection (Banerjee et al. 2002). The serum IgA response to pneumococcal vaccine in older people is diminished with age, as is that of the serum IgM response (Ademokun et al. 2011). While these responses form a small part of the overall serum immunoglobulin response to the vaccine, it is thought that they are key to the antipneumococcal function of serum antibodies (Park and Nahm 2011). Furthermore, in high-throughput sequencing studies, some patients exhibited poor resolution of the immune response after vaccine challenge in terms of reduction of immunoglobulin clonality at day 28 , and this failure was ascribed to $\operatorname{IgA}_{1}$ only (Wu et al. 2012). In the same vaccine study, which compared adults aged 19-45 with those aged 70-89, there was a consistent increased level of $\operatorname{IgG}_{2}$ relative to $\operatorname{IgG}_{1}$ subclass in the older group. In human, $\operatorname{IgG}_{2}$ is the class of antibody produced by T-independent antibodies such as pneumococcal polysaccharides and is limited in its effector abilities as a result of its poor affinity for Fcgamma receptors (Bruhns et al. 2009). Younger adults show a significant qualitative difference in the use of IGHV family genes in the $\mathrm{IgG}_{1}$ and $\mathrm{IgG}_{2}$ repertoire, possibly reflecting different activation and/or tolerance mechanisms in repertoire selection. In contrast, the repertoire of $\mathrm{IgG}_{1}$ in older people is changed such that it more resembles that seen in $\mathrm{IgG}_{2}$, indicating a possible change in activation/tolerance mechanisms with age (Martin et al. 2015).The textbook view of antibody function is that the specificity and affinity for antigen are dependent on Fab, and only the function of the molecule is changed by class switching to a different Fc. However, it has been shown that changing the class of an antibody can affect its fine specificity so class switch is important for more than just changing effector function (Torres et al. 2005). Together these results suggest that future studies on humoral responses should include measurement of all classes of antibody so as not to exclude investigation of some potentially significant functions of B cells.

\section{Affinity Maturation of the B Cell Receptor}

A possible explanation for a decrease in specific antibody is that the process of affinity maturation is defective. Affinity maturation is highly dependent on accessory cells and occurs in the specialized structure of the germinal center in secondary lymphoid tissues. The process involves the expansion of antigen-specific B cells and mutation of their Ig genes (resulting in altered antibody function), followed by selection of the B cells producing the best antibody (Gatto and Brink 2010; Zhang et al. 2016a). Contained within the dynamic microenvironment of the $\mathrm{GC}$ are $\mathrm{B}$ cells, $\mathrm{T}$ cells, and follicular dendritic cells (FDCs) all in close proximity to allow the exchange of costimulatory molecules and cytokine signaling. 


\section{Germinal Center Environment}

In GCs two compartments are established: the dark zone and light zone. Following antigenic stimulation, selected B cells migrate and converge on the GC FDCs, making contact with their long processes (Park and Choi 2005) and differentiating into centroblasts in the dark zone. At the light zone, there is a lower density of B cells (Park and Choi 2005; Gatto and Brink 2010; Bannard et al. 2013). The FDCs are the stromal cells of the GC and play a key role in regulating the humoral immune response (Tew et al. 1997; Gatto and Brink 2010). Unlike antigen-presenting cells (APCs), FDCs present intact antigen-antibody complexes on their cell surface (Zhang et al. 2016a), in the form of immune complexes which are highly immunogenic, and assist GC B cell proliferation (Qin et al. 2000; Li et al. 2000; Bannard et al. 2013). During centroblast proliferation, in the dark zone of the GC, hypermutation of the immunoglobulin (Ig) genes encoding antibody occurs. The B cells move into the light zone, as centrocytes, and will die by apoptosis unless they receive rescue signals conditional on efficient recognition of the antigen by the newly formed B cell receptor. Rescue signals are provided by FDCs and T follicular helper $\left(\mathrm{T}_{\mathrm{FH}}\right)$ cells (Sage and Sharpe 2016). Since FDC and T cell help are limiting, there is competition between B cells, and therefore selection of those B cells with the highest affinity for antigen occurs. The resulting B cells can switch the class of their antibody, from $\operatorname{IgM}$ to $\operatorname{IgG} / \operatorname{IgA} / \operatorname{IgE}$, which also requires $\mathrm{T}$ cell help. B cells with high-affinity antibody differentiate into either memory B cells, to provide for an efficient recall response, or plasma cells to secrete antibody. We have addressed the possible age-related changes in the GC reaction in three main areas: proliferation of B cells, hypermutation of the Ig genes, and selection of high-affinity antigen-specific antibodies.

A defect in B cell proliferation would have severe consequences for the GC reaction, since the loss of cells due to deleterious mutations acquired by hypermutation is extremely large and the pool of B cells required to counter this is therefore also large. For some cell types, proliferating cells can reach replicative senescence - where the telomeres at the ends of the chromosomes erode at each division and therefore there is a limit to the amount of proliferation one cell line can undergo set by the length of the telomere (Goronzy and Weyand 2012). Shorter telomeres in lymphocytes have been associated with higher risk for development of carcinomas (Wu et al. 2003) with higher chances of mortality infectious disease and heart disease in people over 60 years old (Cawthon et al. 2003; Halaschek-Wiener et al. 2008). It has been shown that telomere length decreases with age in T cells and to a lesser extent in B cells (Son et al. 2000; Martens et al. 2002; Weng 2008). However, we do not believe that the proliferative capacity of B cells in the GC is impaired in this way as a result of old age. Telomerase, the enzyme that elongates telomeres, is upregulated in the GC, being high in centroblasts and higher still in centrocytes. This results in B cells leaving the GC for the periphery with substantially longer telomeres than when they first entered, up to $4 \mathrm{~kb}$ longer as determined by Southern blotting (Norrback et al. 2001). Further to this, memory B cells have telomeres on average 2 bp longer than naïve B cells (Martens et al. 2002). 
There has been much debate as to whether the overall size and number of GCs change with age. Rodent models have shown a decrease in GC size and number (Gonzalez-Fernandez et al. 1994; Aydar et al. 2004; Kolar et al. 2006). Immunohistochemical studies measuring the size and overall number of B cell follicles in the human spleen, Peyer's patches (Banerjee et al. 2000), and lymph nodes (Lazuardi et al. 2005) have not shown any age-related difference. However, there have been two studies of the human tonsil, performed by flow cytometry rather than measuring individual GC sizes, which have both reported a decrease in GC B cells with age (Kolar et al. 2006; Mattila and Tarkkanen 1997). Tissue-specific differences may account for these discrepancies and further work would be needed to clarify the issue.

The mutations introduced during somatic hypermutation are generally point mutations, though some insertions and deletions may occur and tend to be in areas containing hotspot motifs (Rogozin and Kolchanov 1992; Spencer et al. 1999; Rogozin and Diaz 2004). There is conflicting opinion regarding whether there is a quantitative change in hypermutation in the aging individual. Reports have indicated no change, a decrease, or increase in mutation with increasing age. The fact that these studies do not agree is hardly surprising as they do not take into account patient health history, i.e. prior immune responses. The tissue origin of samples can also make a significant difference to the number of mutations observed, for example, we have shown consistently that $\mathrm{B}$ cells of mucosal origin have a higher level of mutations than those from, say, the spleen or blood (Banerjee et al. 2002).

We addressed these issues by assessing the frequency of SHM in individual B cell GC expansions. Histologically defined areas of GC from the spleen and Peyer's patch follicles of young and old humans were isolated so that only the mutations in lineages from that particular GC reaction were counted (Banerjee et al. 2002; DunnWalters et al. 2003). There was no difference in the frequency of mutation occurring in human GC reactions in the spleen and Peyer's patch with age. Lineage tree construction can furnish information on the affinity maturation dynamics by measurement of lineage tree shape parameters. Since a failure of adequate selection could result in the production of a population of cells with low affinity, such as is seen in the elderly, we investigated lineage trees from GC reactions in samples from patients of different ages for selection differences. We found a significant decrease in the degree of selection pressure acting on GC B cells in the Peyer's patch of the gut but not the spleen (Banerjee et al. 2002; Dunn-Walters et al. 2003).

An explanation for these apparent changes in selection is still elusive, but several factors could contribute. It may be solely a failure of the quality of B cells in terms of specificity or signaling function. However, since FDCs and CD4+ T cells are important in the selection process, they are also good candidates to investigate for the failure of selection pressure. There is a well-documented age-related decline in thymus size and a reduced $\mathrm{T}$ cell output. Changes in the CD8+ T cell population are dramatic, more so in the face of chronic viral infection such as CMV (WistubaHamprecht et al. 2015). The changes in CD4+ T cell numbers are much more modest, resulting in the CD4/CD8 ratio being a good marker of immune senescence. There is little information as to whether human $\mathrm{T}$ follicular helper cells $\left(\mathrm{T}_{\mathrm{FH}}\right)$ of the $\mathrm{GC}$ are changed in aging. CD40 ligand on $\mathrm{T}_{\mathrm{FH}}$ interacts with CD40 expressed on $\mathrm{B}$ 
cells, and this relationship is critical to T cell-dependent activation of B cell proliferation, memory formation, and class-switch recombination in the GC. Aged CD4 T cells in mice have shown reduced CD40L expression (Eaton et al. 2004) and higher production of IL-10 and IFN (Lefebvre et al. 2016), and these changes are correlated with a decrease in IgG levels reminiscent of the decreased IgG production in response to influenza vaccination in humans.

It has been suggested that the function of FDCs declines with increasing age (Aydar et al. 2004; Shikh et al. 2012). Defects may be intrinsic to the FDCs themselves or may be a failure of the FDC-B cell interactions. FDCs have Fc receptors and complement receptors 1 and 2 on their surface which retain antigen as immune complexes (Yoshida et al. 1993), and these interactions are crucial for the signaling and activation of antigen-specific B cells. Older FDCs fail to properly support the generation of memory $\mathrm{B}$ cells, and induce a reduced number of germinal centers (Aydar et al. 2004), likely as a result of a reduced capacity for holding immune complexes (Szakal et al. 1988). A decrease in immune complex retention and presentation to B cells would lead to lowered B cell activation in the GC.

\section{Intrinsic B Cell Changes with Age}

Although there is clearly a role for accessory cell failure in the age-related changes in germinal center responses, changes intrinsic to the $\mathrm{B}$ cell itself are also responsible. The key enzyme in affinity maturation of $\mathrm{B}$ cells is activation-induced cytidine deaminase (AID), which is directly responsible for both hypermutation of Ig genes and class switching. AID expression is regulated by the E2A-encoded transcription factor E47. E47 and AID expression are reduced in old B cells (Frasca et al. 2005), and this reduction is in turn due to the action of tristetraprolin, a controller of RNA stability (Frasca et al. 2008). The consequences of reduced AID function, given its importance in affinity maturation, would be predicted to be a reduction in highaffinity antibodies. Indeed the polyclonal antibody response produced in response to H1N1 vaccination is of lower affinity when levels of AID are lower, and the levels of AID were also seen to decrease with age (Khurana et al. 2012). Other intrinsic B cell changes occur. The decision of whether to differentiate into a memory cell or a plasma cell (PC) is dependent on the regulation of transcription factors such as Blimp-1 (Klein and Dalla-Favera 2008; Martins and Calame 2008). Blimp-1 has been shown to be significantly reduced in ex vivo B cells from older people (Frasca et al. 2016), and older people have less plasma cells in their bone marrow (Pritz et al. 2015).

\section{The Older B Cell Receptor Repertoire}

Evidence from our lineage tree studies on individual germinal centers (Banerjee et al. 2002) indicated that in some instances the founder B cells of a germinal center may have already been mutated. This occurred more often in the older samples and led us to postulate that B cells which have previously been through the affinity maturation 
process might be reused in subsequent immune responses. If the starting population of $\mathrm{B}$ cells has already been modified in response to a different antigen, then its ability to effectively change to accommodate a new antigen may be compromised. It is now well established, in mice, that naïve B cell output into the periphery decreases with age. It is known that $\mathrm{B}$ cell precursors in humans are also reduced with aging (Kuranda et al. 2011), which is likely to lead to reduced B cell output from the human bone marrow, and the fact that children reconstitute B cell function after bone marrow transplants more rapidly than adults do would support this (Savage et al. 2001).

Since B cell memory appears to be maintained by proliferation (Macallan et al. 2005), it is possible that proliferating memory B cell clones make up for any shortfall in immunological space caused by lower naïve B cell input. This leads us to postulate that GC reactions in older individuals may use "second hand" B cells more often, which would have consequences for B cell diversity. A diverse and functional repertoire of antibodies is essential to produce an effective humoral immune response. If the repertoire of B and plasma cells is reduced, then the ability to recognize foreign antigen is severely compromised. B cell diversity and antibody specificity are defined during the early stages of B lymphocyte differentiation, where the Ig genes are formed. The remarkable way in which gene segment rearrangement forms a complete Ig gene from different segments results in millions of different B cells, each with a unique Ig sequence capable of producing antibody with distinctive specificity (Fig. 3). Briefly, the Ig molecule consists of both heavy and light chains. There are three types of gene segments: variable (V), diversity (D, heavy chain only), and joining $(\mathrm{J})$. The segments are randomly recombined to generate a VDJ for the heavy chain or VJ for the light chain. Thus a germline repertoire of 176 different $\mathrm{V}$, $\mathrm{D}$, or J genes can result in a possible 8,408 different gene rearrangements. Combination of the heavy and light chains results in over 3.7 million combinations. The region where the junctions join together is further diversified by an incomplete joining process. Addition and deletion of nucleotides by terminal deoxynucleotidyl transferase (TdT) activity at these joints lead to junctional diversity. The VDJ joining region of the heavy chain, the $\mathrm{CDRH} 3$ region, is so highly variable that it can be considered to be a fingerprint for that particular gene and the $\mathrm{B}$ cell (and its progeny) that carries it.

\section{Dysregulation of the Repertoire in Older People}

Prior to the advent of high-throughput sequencing methods, the best general assessment of repertoire diversity was by using spectratype analysis. This would give a quantitative estimation of repertoire disruption based on divergence away from a Gaussian distribution of $\mathrm{CDRH} 3$ lengths. In this way, we could show that dysregulated repertoires were more common in older people and were associated with frailty (Gibson et al. 2009). Spectratypes also indicated that a failure in the resolution of the immune response might occur in older people and that there were significant changes in CDRH3 length overall (Ademokun et al. 2011). However, although a spectratype is a relatively inexpensive way to investigate large cohorts of 

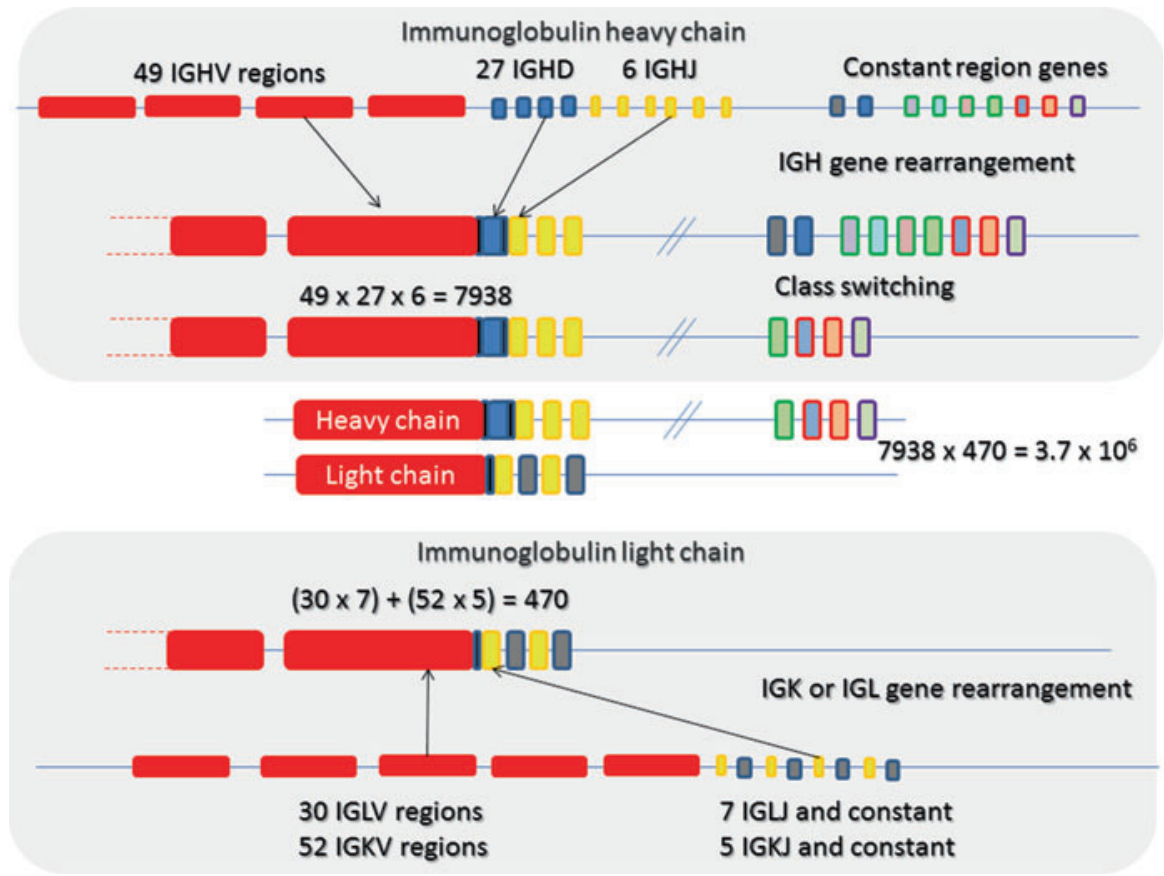

Fig. 3 Generation of immunoglobulin diversity. During germline Ig gene rearrangement, a variable (V) region is joined to a diversity (D) region and a joining (J) region for heavy chain. Light chain rearrangements can be either kappa or lambda and do not have D regions. During the rearrangement process, random $\mathrm{N}$-nucleotides $(\mathrm{N})$ are inserted into the junctions to form a unique CDR3 sequence. In this way, a huge number of different Ig genes are created, with correspondingly large antigen-binding possibilities. Selection processes will act on the repertoire to exclude potentially autoreactive sequences and favor sequences encoding useful antibodies. A study of the various characteristics within the repertoire can provide insight into age-related changes in $\mathrm{B}$ cell development (Adapted from Dunn-Walters (2016) with numbers of germline immunoglobulin genes taken from IMGT databases Lefranc (2016))

individuals, there is no qualitative information on the repertoire as a whole. Even high-throughput repertoire sequencing has its limitations when it comes to sampling the whole repertoire (Boyd et al. 2013), but a number of studies have confirmed the presence of age-related changes such as clonal expansions (Wu et al. 2012; Jiang et al. 2013), change in CDRH3 character (Wu et al. 2011; Wang et al. 2013; Martin et al. 2015), and change in class switching and subclass distribution (Rubelt et al. 2012; Galson et al. 2015; Martin et al. 2015).

\section{Positive and Negative Selection}

There is no evidence in humans that the mechanisms creating diversity in the antibody repertoire are changed with age. Therefore we assume that changes in repertoire that do occur with age will be as a result of subsequent environmental 
selection forces. Positive selection events can have a huge difference on the repertoire - where the antigen-specific cells are expanded and, in some instances, undergo affinity maturation in a germinal center. As outlined above, these events are all affected by age and will affect the memory B cell repertoire. One key difference in the repertoire after an immune response is in the size and physicochemical character of the CDRH3 region, a region which is crucial for antigen binding (Wu et al. 2011). This occurs regardless of the activating antigen. At first sight, it might seem that a small CDRH3 size is beneficial to exogenous antigen binding. However there is also a decrease in CDRH3 size as B cells mature in the bone marrow so a more likely explanation is that larger $\mathrm{CDRH} 3$ sizes are deleterious in some way, presumably with autoreactive potential, and so are removed from the repertoire. Crucially, this decrease in CDRH3 size is not so obvious in samples from older people (DunnWalters 2016), indicating that the tolerogenic selection events are decreased in older people and perhaps providing an explanation for the observations of increased autoreactive antibodies with age discussed above.

\section{Interaction of Humoral Immunity with Other Systems}

There are a number of areas where other physiological systems interact with the immune system, and since aging is a whole body phenomenon, we need to take a more holistic view of the mechanisms of immune failure. Cross-disciplinary work that this requires is rare, but there are a few studies which indicate that there are important lessons to be learned and provide a tantalizing glimpse into the complexity of interrelationships.

Metabolic processes are important for all cells, and immune cells are no exception although data is limited. A transcript analysis has shown an association between memory B cell generation and cholesterol/lipid metabolic pathways in influenza vaccination (Haralambieva et al. 2016). Similarly, in mice, transcriptomic analysis identified metabolic pathways and the ER stress response pathways as being changed with age. Validation studies showed defects in glucose catabolism, oxidative phosphorylation, and increased reactive oxygen species in B cells with age (Kannan et al. 2016). Since obesity and metabolic syndrome are increased with age, the BMI of study subjects may be a confounding factor in age-related B cell studies. Obesity has been associated with attenuated influenza vaccine responses, decreased percentage of switched memory and transitional B cells, and an increased percentage of pro-inflammatory late/exhausted memory B cells (Frasca et al. 2016). Human B1 $\mathrm{B}$ cells have been identified in visceral adipose tissue and may well have a protective effect (Harmon et al. 2016). However, it has also been suggested that B cells can be activated by products of lipolysis in visceral adipose tissue to release pro-inflammatory mediators, thus contributing to local and systemic inflammation (Nikolajczyk 2010). mTOR pathways, autophagy, and the unfolded protein response are all processes that have been associated with aging (Perl 2015; Taylor 2016; Zhang et al. 2016b) and have also been shown to be important in plasma cell function (Tellier et al. 2016; Arnold et al. 2016). Since plasma cell numbers in the bone marrow of older people have been reported to decrease with age (Pritz et al. 
2015), then there may be common cellular changes with age that are particularly relevant to the humoral immune response.

Circadian rhythms have an effect on physiology and are known to change with age (Banks et al. 2016). Chronicity in blood lymphocyte composition, including of B cells, is observed in younger adults and decreases with age (Mazzoccoli et al. 2011). Chronicity is therefore likely to be important in determining responses to challenge; indeed a study of older adults (over age 65) found that the antibody response to vaccination against influenza was greater if the vaccine was administered in the morning than in the afternoon (Long et al. 2016). The exact mechanism by which chronicity affects the immune system is not known; many homeostatic physiological mediators also vary with time. One possibility is the effect of cortisol, and there are reports that stress can depress the efficacy of the immune system in old age (Duggal et al. 2015), a fact that is particularly relevant for the health and well-being of older people who are often subject to stresses of ill health and bereavement. Many different aspects of immunity are affected by an imbalance of DHEA/cortisol, including the lowering of antibody production from B cells (Buford and Willoughby 2008).

The exercise and nutritional habits of older people can also be affected by movement-restrictive comorbidity and issues of dentition. Humoral immunity is dramatically affected by lack of exercise (Hoff et al. 2015), and poor nutrition can affect a large number of different immune parameters (Lesourd 2004). Nutritional changes themselves will affect the microbiota. Experiments in mice clearly show changed B cell development in response to changes in tryptophan availability and microbial diversity (van Beek et al. 2016). It is clear that relatively simple changes in lifestyle factors can have substantial effects on immune function.

\section{Cancer}

B cells themselves are subject to malignant transformation, and many cancers such as leukemias/lymphomas can be age-related. In addition, tumor-infiltrating lymphocytes are critical in the control, or not, of tumor growth in malignancies of non-lymphocyte origin. The role of B cells is not yet fully understood, since they may contribute to the immune response against tumors in either a positive or a negative manner, depending on the type of B cell in the tissue. A systemic antibody change might also affect tumorigenesis; it has been suggested that the increase in ANA antibodies seen with age may have beneficial effects by virtue of a possible antitumor activity (Torchilin et al. 2001). Whether there are tumor antigen-specific humoral effects is in question, but since most cancers increase with age, we should make efforts to understand the role of the aging B cell repertoire in cancer.

\section{Monoclonal Expansions and Lymphomas}

Expansions of B cells/plasma cells in the absence of any apparent exogenous challenge could be due to a number of factors. It may indeed be true that a decreasing 
naïve $B$ cell output in the face of homeostatic mechanisms to keep the total number of B cells the same has resulted in the repertoire being increasingly made up of antigen-experienced expansions of cells. There may actually be an underlying infection, but the normal febrile symptoms by which we recognize as infection do not show due to the effects of immune senescence or a failure to resolve a response from a prior infection in a timely manner. A high-throughput repertoire study of individuals of known seropositivity status for the chronic viral infections CMV and EBV has shown that EBV, but not CMV, can cause an increase in clonal expansions in the repertoire (Wang et al. 2014). Alternatively there may be pathological monoclonal expansions of B cells, such as are seen in leukemia or lymphoma. Usually, these are diagnosed conditions, and individuals with this sort of medical history are excluded from studies on B cell diversity. However, it might be possible that a preclinical condition exists in some people. An increase in monoclonal expansions of B cells, both of CD5+ and CD5- phenotype, has previously been reported in older people (Ghia et al. 2004). Monoclonal gammopathy of undetermined significance (MGUS) is a predominant plasma cell disorder (Kyle et al. 2006) and has been shown to increase with age in both humans (Kyle et al. 2006) and mouse (Radl 1990). It is characterized by an increase in the presence of serum monoclonal Ig. MGUS is not found in young subjects, is prevalent in around $2 \%$ of over $50 \mathrm{~s}$, and has been reported to vary in the elderly from $11 \%$ to $38 \%$ (Kyle et al. 2002). There is an association between MGUS and onset of multiple myeloma or related malignant condition with average risk assessed at about $1 \%$ per year (Kyle and Vincent Rajkumar 2003). A vaccination study of MGUS patients showed poor vaccine responses and indicated that the recruitment of $\mathrm{B}$ cells to the immune response was compromised by the prior existence of expanded clones (Tete et al. 2015). Hence while one danger of MGUS is in potential transformation to malignancy later in life, another key risk is in susceptibility to infection. One might assume that in older people without MGUS, but with inappropriate expansions of $\mathrm{B}$ cells (as mentioned above), this would also be the case. Other malignancies of $\mathrm{B}$ cells other than myeloma are age-associated; a prime example is chronic lymphocytic leukemia (CLL), which is thought to arise from a premalignant monoclonal B cell lymphocytosis (MBL) that also carries a risk of susceptibility to infection (Whitaker et al. 2014; Scarfò and Ghia 2016). The B cell receptors encoded by CLL are autoreactive (Herve et al. 2005), and hence we think that the expansion of potentially autoreactive B cells in older age is a likely contributor to malignant transformative events.

\section{Role of B Cells in Antitumor Activity}

The presence of B cells in several tumor types (colorectal, breast, lung, and gastric cancers) has been strongly associated with improved prognosis in a number of studies (Nelson 2010; Hennequin et al. 2015). This may be as a result of their role as antigen-presenting cells, thus aiding the tumor-infiltrating $\mathrm{T}$ cells, or may be a function dependent on their antibody (Nelson 2010; Lee-Chang et al. 2014). It is interesting to note that the age-associated $4-1 \mathrm{BBL}+\mathrm{B}$ cells make excellent antigen- 
presenting cells that can activate CD8 $+\mathrm{T}$ cells and therefore stimulate antitumor activity (Lee-Chang et al. 2016). B cell infiltrates may be diffused or aggregated into tertiary lymphoid structures, in some cases recapitulating germinal center morphology. Clonal expansions of switched B cells have been shown in melanoma, where the presence of B cells is also thought to be beneficial (Saul et al. 2016). However, experiments in mice have indicated that tumor-infiltrating B cells can be regulatory, causing downregulation of the antitumor response, and the presence of $\mathrm{B}$ regs in a number of solid tumors (e.g., pancreatic, ovarian, esophageal, hepatocellular carcinoma) has been predicted to aid tumor growth by inhibition of $\mathrm{T}$ cell activity and promotion of inflammatory growth effects (Schwartz et al. 2016). B regs in human PBMCs are of the IgM class, so perhaps distinguishing tumor B cells by class of antibody might aid in discriminating between the different functional effects. It has been suggested that aged human monocytes can convert B cells with regulatory capacity into antitumor 4-1BBL+ B cells (Lee-Chang et al. 2016). It seems that much more work is needed to elucidate the exact role of tumor-infiltrating B cells in different types of tumor.

\section{Summary}

In recent years, the role of the $\mathrm{B}$ cell in the immune response has been recognized as being much more than simply a factory to produce antibody. Thus the field of B cell immunology is in an exciting phase where there are many unanswered questions with respect to immune regulation and tumor immune responses; both these topics are of particular importance for older people. In addition, there is much scope for investigating $B$ cell responses outside the textbook $\mathrm{T}$-dependent $\mathrm{IgG}_{1}$ antibody production. Many key age-related changes are in T-independent responses which would involve $\operatorname{IgM}, \operatorname{IgG}_{2}$, and $\operatorname{IgA}$ - particularly at mucosal surfaces mucosal surfaces which are often the first to encounter external pathogens and which and which may be involved in educating the host humoral immune system with respect to distinguishing inappropriate activation signals. The overall picture we currently have of B cell immunity in aging is that of a system sufficient in number and quality at the very start of development, but with some breakdown in the selection controls balancing appropriate versus inappropriate activation signals.

Acknowledgments The authors would like to acknowledge the following support for our aging research: the Dunhill Medical Trust, Research into Ageing, the Rosetrees Trust, the Human Frontiers Science Program, MRC, and BBSRC.

\section{References}

Ademokun A, Wu YC, Dunn-Walters D (2010) The ageing B cell population: composition and function. Biogerontology 11(2):125-137. https://doi.org/10.1007/s10522-009-9256-9

Ademokun A, Wu YC, Martin V, Mitra R, Sack U, Baxendale H, Kipling D, Dunn-Walters DK (2011) Vaccination-induced changes in human B-cell repertoire and pneumococcal IgM and IgA 
antibody at different ages. Aging Cell 10(6):922-930. https://doi.org/10.1111/j.1474-9726. 2011.00732.x

Albright JF, Albright JW (2003) Aging, immunity, and infection. Humana Press, New Jersey

AlonsoDeVelasco E, Verheul AF, Verhoef J, Snippe H (1995) Streptococcus pneumoniae: virulence factors, pathogenesis, and vaccines. Microbiol Rev 59(4):591-603. http://www.pubmedcentral. nih.gov/articlerender.fcgi?artid $=239389 \&$ tool $=$ pmcentrez\&rendertype $=$ abstract

Andersen-Ranberg K, Høier-Madsen M, Wiik A, Jeune B, Hegedüs L (2004) High prevalence of autoantibodies among danish centenarians. Clin Exp Immunol 138(1):158-163. https://doi.org/ 10.1111/j.1365-2249.2004.02575.x

Arnaboldi PM, Behr MJ, Metzger DW (2005) Mucosal B cell deficiency in IgA-/- mice abrogates the development of allergic lung inflammation. J Immunol 175(2):1276-1285. https://doi.org/ 10.4049/jimmunol.175.2.1276

Arnold J, Murera D, Arbogast F, Fauny JD, Muller S, Gros F (2016) Autophagy is dispensable for B-cell development but essential for humoral autoimmune responses. Cell Death Differ 23 (5):853-864. https://doi.org/10.1038/cdd.2015.149

Aydar Y, Balogh P, Tew JG, Szakal AK (2004) Follicular dendritic cells in aging, A 'bottle-Neck' in the humoral immune response. Ageing Res Rev 3(1):15-29. https://doi.org/10.1016/j. arr.2003.08.002

Bagnara D, Squillario M, Kipling D, Mora T, Walczak AM, Da Silva L, Weller S, Dunn-Walters DK, Weill J-C, Reynaud C-A (2015) A reassessment of IgM memory subsets in humans. J Immunol 195(8):3716-24. https://doi.org/10.4049/jimmunol.1500753

Bancos S, Phipps RP (2010) Memory B cells from older people express normal levels of cyclooxygenase- 2 and produce higher levels of IL-6 and IL-10 upon in vitro activation. Cell Immunol 266(1):90-97. https://doi.org/10.1016/j.cellimm.2010.09.002

Banerjee M, Sanderson JD, Spencer J, Dunn-Walters DK (2000) Immunohistochemical analysis of ageing human B and T cell populations reveals an age-related decline of CD8 T cells in spleen but not Gut-Associated Lymphoid Tissue (GALT). Mech Ageing Dev 115:85-99. https://doi. org/10.1016/S0047-6374(00)00106-8

Banerjee M, Mehr R, Belelovsky A, Spencer J, Dunn-Walters DK (2002) Age- and tissue-specific differences in human germinal center B cell selection revealed by analysis of IgVH gene hypermutation and lineage trees. Eur J Immunol 32(7):1947-1957. https://doi.org/10.1002/ 1521-4141(200207)32:7<1947::AID-IMMU1947>3.0.CO;2-1

Banks G, Nolan PM, Peirson SN (2016) Reciprocal interactions between circadian clocks and aging. Mamm Genome 27(7-8):332-340. https://doi.org/10.1007/s00335-016-9639-6

Bannard O, Horton RM, Allen CDC, An J, Nagasawa T, Cyster JG (2013) Germinal center centroblasts transition to a centrocyte phenotype according to a timed program and depend on the dark zone for effective selection. Immunity 39(5):912-924. https://doi.org/10.1016/j. immuni.2013.08.038

Barr TA, Shen P, Brown S, Lampropoulou V, Roch T, Lawrie S, Fan B et al (2012) B cell depletion therapy ameliorates autoimmune disease through ablation of IL-6-producing B cells. J Exp Med 209(5):1001-1010. https://doi.org/10.1084/jem.20111675

Barrett DJ, Ayoub EM (1986) IgG2 subclass restriction of antibody to pneumococcal polysaccharides. Clin Exp Immunol 63:127-134

Berkowska MA, Schickel JN, Grosserichter-Wagener C, de Ridder D, Ng YS, van Dongen JJ, Meffre E, van Zelm MC (2015) Circulating human CD27-IgA+ memory B cells recognize bacteria with polyreactive Igs. J Immunol 195(4):1417-1426. https://doi.org/10.4049/jimmuno 1.1402708

Birch C, Gowardman J (2000) Streptococcus pyogenes: a forgotten cause of severe communityacquired pneumonia. Anaesth Intensive Care 28(1):87-90

Boyd SD, Liu Y, Wang C, Martin V, Dunn-Walters DK (2013) Human lymphocyte repertoires in ageing. Curr Opin Immunol 25(4):511-515. https://doi.org/10.1016/j.coi.2013.07.007

Brieland JK, Heath LA, Huffnagle GB et al (1996) Humoral immunity and regulation of intrapulmonary growth of Legionella pneumophila in the immunocompetent host. J Immunol 157(11):5002-5008 
Brinkhof MWG, Spoerri A, Birrer A, Hagman R, Koch D, Zwahlen M (2006) Influenza-attributable mortality among the elderly in Switzerland. Swiss Med Wkly 136(19-20):302-310. http://dx. doi.org/2006/19/smw-11373

Brown JS, Hussell T, Gilliland SM, Holden DW, Paton JC, Ehrenstein MR, Walport MJ, Botto M (2002) The classical pathway is the dominant complement pathway required for innate immunity to streptococcus pneumoniae infection in mice. Proc Natl Acad Sci USA 99(26): 16969-16974. https://doi.org/10.1073/pnas.012669199

Bruhns P, Iannascoli B, England P, Mancardi DA, Fernandez N, Jorieux S, Daëron M (2009) Specificity and affinity of human $\mathrm{Fc} \gamma$ receptors and their polymorphic variants for human IgG subclasses. Blood 113(16):3716-3725. https://doi.org/10.1182/blood-2008-09-179754

Buford TW, Willoughby DS (2008) Impact of DHEA(S) and cortisol on immune function in aging: a brief review. Appl Physiol Nutr Metab = Physiologie Appliquée, Nutrition et Métabolisme 33(3):429-433. https://doi.org/10.1139/H08-013

Bugatti S, Vitolo B, Caporali R, Montecucco C, Manzo A (2014) B cells in rheumatoid arthritis: from pathogenic players to disease biomarkers. Biomed Res Int 681678. https://doi.org/ $10.1155 / 2014 / 681678$

Bulati M, Buffa S, Candore G, Caruso C, Dunn-Walters DK, Pellicanò M, Wu YC, Romano GC (2011) B cells and immunosenescence: a focus on IgG+IgD-CD27- (DN) B cells in aged humans. Ageing Res Rev. 10(2):274-84. https://doi.org/10.1016/j.arr.2010.12.002

Bulati M, Buffa S, Martorana A, Candore G, Lio D, Caruso C, Colonna-Romano G (2014) Trafficking phenotype and production of granzyme B by double negative B cells (IgG+IgDCD27-) in the elderly. Exp Gerontol 54:123-129. https://doi.org/10.1016/j.exger.2013.12.011

Campisi J, Andersen JK, Kapahi P, Melov S (2011) Cellular senescence: a link between cancer and age-related degenerative disease? Semin Cancer Biol. 21(6):354-9. https://doi.org/10.1016/ j.semcancer.2011.09.001

Capolunghi F, Manuela Rosado M, Sinibaldi M, Aranburu A, Carsetti R (2013) Why do we need IgM memory B cells? Immunol Lett. 152(2):114-20. https://doi.org/10.1016/j. imlet.2013.04.007

Cawthon RM, Smith KR, O'Brien E, Sivatchenko A, Kerber RA (2003) Association between telomere length in blood and mortality in people aged 60 years or older. Lancet 361(9355): 393-395. https://doi.org/10.1016/S0140-6736(03)12384-7

Colonna-Romano G, Aquino A, Bulati M, Di Lorenzo G, Listì F, Vitello S, Lio D, Candore G, Clesi G, Caruso C (2006) Memory B cell subpopulations in the aged. Rejuvenation Res 9(1): 149-152. https://doi.org/10.1089/rej.2006.9.149

Crawford A, MacLeod M, Schumacher T, Corlett L, Gray D (2006) Primary T cell expansion and differentiation in vivo requires antigen presentation by B cells. J Immunol 176(6):3498-3506. https://doi.org/10.4049/jimmunol.176.6.3498

Deo SS, Vaidva AK (2004) Elevated levels of secretory immunoglobulin a (sIgA) in urinary tract infections. Indian J Pediatr 71(1):37-40

Duggal NA, Upton J, Phillips AC, Sapey E, Lord JM (2013) An age-related numerical and functional deficit in CD19(+) CD24(hi) CD38(hi) B cells is associated with an increase in systemic autoimmunity. Aging Cell 12(5):873-881. https://doi.org/10.1111/acel.12114

Duggal NA, Upton J, Phillips AC, Hampson P, Lord JM (2015) NK cell immunesenescence is increased by psychological but not physical stress in older adults associated with raised cortisol and reduced perforin expression. Age 37(1):1. https://doi.org/10.1007/s11357-015-9748-2

Dunn-Walters DK (2016) The ageing human B cell repertoire: a failure of selection? Clin Exp Immunol 183(1):50-56. https://doi.org/10.1111/cei.12700

Dunn-Walters DK, Ademokun AA (2010) B cell repertoire and ageing. Curr Opin Immunol 22(4): 514-520. https://doi.org/10.1016/j.coi.2010.04.009

Dunn-Walters DK, Isaacson PG, Spencer J (1995) Analysis of mutations in immunoglobulin heavy chain variable region genes of microdissected marginal zone (MGZ) B cells suggests that the MGZ of human spleen is a reservoir of memory B cells. J Exp Med 182(2):559-566

Dunn-Walters DK, Banerjee M, Mehr R (2003) Effects of age on antibody affinity maturation. Biochem Soc Trans 31(2):447-448. https://doi.org/10.1042/bst0310447 
Eaton SM, Burns EM, Kusser K, Randall TD, Haynes L (2004) Age-related defects in CD4 T cell cognate helper function lead to reductions in humoral responses. J Exp Med 200(12): 1613-1622. https://doi.org/10.1084/jem.20041395

El Shikh MEM, Pitzalis C (2012) Follicular dendritic cells in health and disease. Front Immunol. 3:292. https://doi.org/10.3389/fimmu.2012.00292

Falsey AR, Hennessey PA, Formica MA, Cox C, Walsh EE (2005) Respiratory syncytial virus infection in elderly and high-risk adults. N Engl J Med 352(17):1749-1759. https://doi.org/ 10.1056/NEJMoa043951

Fourati S, Cristescu R, Loboda A, Talla A, Filali A, Railkar R, Schaeffer AK et al (2016) Pre-vaccination inflammation and B-cell signalling predict age-related hyporesponse to Hepatitis B vaccination. Nat Commun 7:10369. https://doi.org/10.1038/ncomms10369

Frasca D, Blomberg BB (2009) Effects of aging on B cell function. Curr Opin Immunol. 21(4):425-30. https://doi.org/10.1016/j.coi.2009.06.001

Frasca D, Blomberg BB (2014) B cell function and influenza vaccine responses in healthy aging and disease. Curr Opin Immunol 29:112-118. https://doi.org/10.1016/j.coi.2014.05.008

Frasca D, Riley RL, Blomberg BB (2005) Humoral immune response and B-cell functions including immunoglobulin class switch are downregulated in aged mice and humans. Semin Immunol. 17(5):378-84. https://doi.org/10.1016/j.smim.2005.05.005

Frasca D, Landin AM, Lechner SC, Ryan JG, Schwartz R, Riley RL, Blomberg BB (2008) Aging down-regulates the transcription factor $\mathrm{E} 2 \mathrm{~A}$, activation-induced cytidine deaminase, and $\mathrm{Ig}$ class switch in human B cells. J Immunol. 180(8):5283-90. https://doi.org/10.4049/ jimmunol.180.8.5283

Frasca D, Diaz A, Romero M, Blomberg BB (2016) The generation of memory B cells is maintained, but the antibody response is not, in the elderly after repeated influenza immunizations. Vaccine. https://doi.org/10.1016/j.vaccine.2016.04.023

Galson JD, Trück J, Fowler A, Münz M, Cerundolo V, Pollard AJ, Lunter G, Kelly DF (2015) In-depth assessment of within-individual and inter-individual variation in the B cell receptor repertoire. Front Immunol 6(OCT):531. https://doi.org/10.3389/fimmu.2015.00531

Gatto D, Brink R (2010) The germinal center reaction. J Allergy Clin Immunol. 126(5):898-907. https://doi.org/10.1016/j.jaci.2010.09.007

Genton B, D'Acremont V, Furrer HJ, Hatz C, Loutan L (2006) Hepatitis A vaccines and the elderly. Travel Med Infect Dis 4(6):303-312. https://doi.org/10.1016/j.tmaid.2005.10.002

Ghia P, Prato G, Scielzo C, Stella S, Geuna M, Guida G, Caligaris-Cappio F (2004) Monoclonal CD5+ and CD5- B-lymphocyte expansions are frequent in the peripheral blood of the elderly. Blood 103(6):2337-2342

Gibson KL, Wu Y-C, Barnett Y, Duggan O, Vaughan R, Kondeatis E, Nilsson B-O, Wikby A, Kipling D, Dunn-Walters DK (2009) B cell diversity decreases in old age and is correlated with poor health status. Ageing Cell 8:18-25

Gonzalez-Fernandez A, Gilmore D, Milstein C (1994) Age-related decrease in the proportion of germinal center B cells from mouse Peyer's patches is accompanied by all accumulation of somatic mutations in their immunoglobulin genes. Eur J Immunol 24(11):2918-2921. https:// doi.org/10.1002/eji.1830241151

Goodeve A, Potter CW, Clark A, Jennings R, Schild GC, Yetts R (1983) A graded-dose study of inactivated, surface antigen influenza B vaccine in volunteers: reactogenicity, antibody response and protection to challenge virus infection. J Hyg 90(1):107-115. https://doi.org/10.1017/ S0022172400063907

Goronzy JJ, Weyand CM (2012) Immune aging and autoimmunity. 69(10):1615-23. Cell Mol Life Sci. https://doi.org/10.1007/s00018-012-0970-0

Goronzy JJ, Weyand CM (2013) Understanding immunosenescence to improve responses to vaccines. Nat Immunol 14(5):428-436. https://doi.org/10.1038/ni.2588

Hageman JC, Uyeki TM, Francis JS, Jernigan DB, Gary Wheeler J, Bridges CB, Barenkamp SJ et al (2006) Severe community-acquired pneumonia due to staphylococcus aureus, 2003-04 influenza season. Emerg Infect Dis 12(6):894-899. https://doi.org/10.3201/eid1206.051141 
Hainz U, Jenewein B, Asch E, Pfeiffer KP, Berger P, Grubeck-Loebenstein B (2005) Insufficient protection for healthy elderly adults by tetanus and TBE vaccines. Vaccine 23(25):3232-3235. https://doi.org/10.1016/j.vaccine.2005.01.085

Halaschek-Wiener J, Vulto I, Fornika D, Collins J, Connors JM, Le ND, Lansdorp PM, BrooksWilson A (2008) Reduced telomere length variation in healthy oldest old. Mech Ageing Dev 129(11):638-641. https://doi.org/10.1016/j.mad.2008.07.004

Haralambieva IH, Ovsyannikova IG, Kennedy RB, Zimmermann MT, Grill DE, Oberg AL, Poland GA (2016) Transcriptional signatures of influenza A/H1N1-specific IgG memory-like B cell response in older individuals. Vaccine 34(34):3993-4002. https://doi.org/10.1016/j.vaccine.2016.06.034. Epub 2016 Jun 20

Harmon DB, Srikakulapu P, Kaplan JL, Oldham SN, McSkimming C, Garmey JC, Perry HM et al (2016) Protective role for B-1b B cells and IgM in obesity-associated inflammation, glucose intolerance, and insulin resistance. Arterioscler Thromb Vasc Biol 36(4):682-691. https://doi. org/10.1161/ATVBAHA.116.307166

Harvey BS, Baker CJ, Edwards MS (1992) Contributions of complement and immunoglobulin to neutrophil-mediated killing of enterococci. Infect Immun 60(9):3635-3640

Hennequin A, Derangère V, Boidot R, Apetoh L, Vincent J, Orry D, Fraisse J et al (2015) Tumor infiltration by Tbet + Effector T cells and CD20+B cells is associated with survival in gastric cancer patients. OncoImmunology. 5(2):e1054598. https://doi.org/10.1080/ 2162402X.2015.1054598

Herve M, Xu K, Ng YS, Wardemann H, Albesiano E, Messmer BT, Chiorazzi N, Meffre E (2005) Unmutated and mutated chronic lymphocytic leukemias derive from self-reactive B cell precursors despite expressing different antibody reactivity. J Clin Investig 115(6):1636-1643. https://doi.org/10.1172/JCI24387

Hoff P, Belavy DL, Huscher D, Lang A, Hahne M, Kuhlmey AK, Maschmeyer P et al (2015) Effects of 60-day bed rest with and without exercise on cellular and humoral immunological parameters. Cell Mol Immunol 12(4):483-492. https://doi.org/10.1038/cmi.2014.106

Höpping M, Ana JME, Fonville JM, Powers DC, Beyer WEP, Smith DJ (2016) The confounded effects of age and exposure history in response to influenza vaccination. Vaccine 34(4):540-546. https://doi.org/10.1016/j.vaccine.2015.11.058

Hurme M, Korkki S, Lehtimäki T, Karhunen PJ, Jylhä M, Hervonen A, Pertovaara M (2007) Autoimmunity and longevity: presence of antinuclear antibodies is not associated with the rate of inflammation or mortality in nonagenarians. Mech Ageing Dev 128(5-6):407-408. https:// doi.org/10.1016/j.mad.2007.03.001

Ioannidis JP, Katsifis GE, Stavropoulos ED et al (2003) Evaluation of the association of autoantibodies with mortality in the very elderly: a cohort study. Rheumatology (Oxford) 42(2):357-361

Jiang N, He J, Weinstein JA, Penland L, Sasaki S, He X-S, Dekker CL et al (2013) Lineage structure of the human antibody repertoire in response to influenza vaccination. Sci Transl Med 5(171): 171ra19. https://doi.org/10.1126/scitranslmed.3004794

Kannan S, Kossenkov A, Kurupati RK, Xiang JZQ, Doyle SA, Schmader KE, Schowe L, Ertl HC (2015) A shortened interval between vaccinations with the trivalent inactivated influenza vaccine increases responsiveness in the aged. Aging 7(12):1077-1085

Kannan S, Dawany N, Kurupati R, Showe LC, Ertl HCJ (2016) Age-related changes in the transcriptome of antibody-secreting cells. Oncotarget. https://doi.org/10.18632/oncotarget.7958

Kantele A, Mottonen T, Ala-Kaila K et al (2003) P fimbria-specific B cell responses in patients with urinary tract infection. J Infect Dis 188(12):1885-1891

Keitel WA, Atmar RL, Cate TR, Petersen NJ, Greenberg SB, Ruben F, Couch RB (2006) Safety of high doses of influenza vaccine and effect on antibody responses in elderly persons. Arch Intern Med 166(10):1121-1127. https://doi.org/10.1001/archinte.166.10.1121

Khurana S, Frasca D, Blomberg B, Golding H (2012) AID activity in B cells strongly correlates with polyclonal antibody affinity maturation in-vivo following pandemic 2009-H1N1 vaccination in humans. PLoS Pathog 8(9):e1002920 
Klein U, Dalla-Favera R (2008) Germinal centres: role in B-cell physiology and malignancy. Nat Rev Immunol 8(1):22-33. https://doi.org/10.1038/nri2217

Koivula I, Stén M, Leinonen M, Mäkelä PH (1997) Clinical efficacy of pneumococcal vaccine in the elderly: a randomized, single-blind population-based trial. Am J Med 103(4):281-290. https://doi.org/10.1016/S0002-9343(97)00149-6

Kolar GR, Mehta D, Wilson PC, Capra JD (2006) Diversity of the Ig repertoire is maintained with age in spite of reduced germinal centre cells in human tonsil lymphoid tissue. Scand J Immunol 64(3):314-324. https://doi.org/10.1111/j.1365-3083.2006.01817.x

Kruetzmann S, Rosado MM, Weber H, Germing U, Tournilhac O, Peter HH, Berner R et al (2003) Human immunoglobulin $\mathrm{M}$ memory B cells controlling streptococcus pneumoniae infections are generated in the spleen. J Exp Med 197(7):939-945. https://doi.org/10.1084/jem.20022020. jem.20022020 [pii]

Kuranda K, Vargaftig J, de la Rochere P, Dosquet C, Charron D, Bardin F, Tonnelle C, Bonnet D, Goodhardt M (2011) Age-related changes in human hematopoietic stem/progenitor cells. Aging Cell 10(3):542-546. https://doi.org/10.1111/j.1474-9726.2011.00675.x

Kyle RA, Vincent Rajkumar S (2003) Monoclonal gammopathies of undetermined significance: a review. Immunol Rev 194(4):112-139. https://doi.org/10.1034/j.1600-065X.2003.00056.x

Kyle RA, Therneau TM, Vincent Rajkumar S, Offord JR, Larson DR, Plevak MF, Joseph Melton L (2002) A long-term study of prognosis in monoclonal gammopathy of undetermined significance. N Engl J Med 346(8):564-569. https://doi.org/10.1056/NEJMoa01133202

Kyle RA, Therneau TM, Vincent Rajkumar S, Larson DR, Plevak MF, Offord JR, Dispenzieri A, Katzmann JA, Joseph Melton L (2006) Prevalence of monoclonal gammopathy of undetermined significance. N Engl J Med 354:1362-1369. https://doi.org/10.1007/s12185011-0995-4

Lazuardi L, Jenewein B, Wolf AM, Pfister G, Tzankov A, Grubeck-Loebenstein B (2005) Age-related loss of naïve $\mathrm{T}$ cells and dysregulation of T-cell/B-cell interactions in human lymph nodes. Immunology 114(1):37-43. https://doi.org/10.1111/j.1365-2567.2004.02006.x

Lee-Chang C, Bodogai M, Moritoh K, Olkhanud PB, Chan AC, Croft M, Mattison JA et al (2014) Accumulation of 4-1BBL $+B$ cells in the elderly induces the generation of granzyme-B + CD8+ $\mathrm{T}$ cells with potential antitumor activity. Blood 124(9):1450-1459. https://oi.org/10.1182/ blood-2014-03-563940

Lee-Chang C, Bodogai M, Moritoh K, Chen X, Wersto R, Sen R, Young HA, Croft M, Ferrucci L, Biragyn A (2016) Aging converts innate B1a cells into potent CD8+ T cell inducers. J Immunol 196(8):3385-3397. https://doi.org/10.4049/jimmunol.1502034

Lefebvre JS, Masters AR, Hopkins JW, Haynes L (2016) Age-related impairment of humoral response to influenza is associated with changes in antigen specific $\mathrm{T}$ follicular helper cell responses. Sci Rep 6:25051. https://doi.org/10.1038/srep25051

Lefranc MP (2016) IMGT Database [Internet]. Last updated May 2016. http://www.imgt.org/ IMGTrepertoire/

Lepper PM, Moricke A, Held TK et al (2003) K-antigen-specific, but not O-antigen-specific natural human serium antibodies promote phagocytosis of Klebsiella pneumoniae. FEMS Immunol Med Microbiol 35(2):93-98

Lesourd B (2004) Nutrition: a major factor influencing immunity in the elderly. J Nutr Health Aging $8(1): 28-37$.

Li L, Zhang X, Kovacic S, Long AJ, Bourque K, Wood CR, Choi YS (2000) Identification of a human follicular dendritic cell molecule that stimulates germinal center B cell growth. J Exp Med 191(6):1077-1084. https://doi.org/10.1084/jem.191.6.1077

Linton PJ, Harbertson J, Bradley LM (2000) A critical role for B cells in the development of memory CD4 Cells. J Immunol (Baltimore, Md: 1950) 165(10):5558-5565. http://www.ncbi. nlm.nih.gov/pubmed/12663146

Long JE, Drayson MT, Taylor AE, Toellner KM, Lord JM, Phillips AC (2016) Morning vaccination enhances antibody response over afternoon aaccination: a cluster-randomised trial. Vaccine. 34 (24):2679-85. https://doi.org/10.1016/j.vaccine.2016.04.032 
Lund FE, Hollifield M, Schuer K, Louise Lines J, Randall TD, Garvy BA (2006) B cells are required for generation of protective effector and memory CD4 cells in response to pneumocystis lung infection. J Immunol (Baltimore, Md: 1950) 176(10):6147-6154. doi:176/ $10 / 6147$ [pii]

Lu Y, Tan CT, Nyunt MS, Mok EW, Camous X, Kared H, Fulop T, Feng L, Ng TP, Larbi A (2016) Inflammatory and immune markers associated with physical frailty syndrome: findings from Singapore longitudinal aging studies. Oncotarget 7(20):28783-28795. https://doi.org/10.18632/ oncotarget. 8939

Mabbott NA, Kobayashi A, Sehgal A, Bradford BM, Pattison M, Donaldson DS (2015) Aging and the mucosal immune system in the intestine. Biogerontology. https://oi.org/10.1007/s10522014-9498-z

Macallan DC, Wallace DL, Zhang V, Ghattas H, Asquith B, De Lara C, Worth A et al (2005) B-cell kinetics in humans: rapid turnover of peripheral blood memory cells. Blood 105(9):3633-3640. https://doi.org/10.1182/blood-2004-09-3740

Maciosek MV, Solberg LI, Coffield AB, Edwards NM, Goodman MJ (2006) Influenza vaccination. health impact and cost effectiveness among adults aged 50 to 64 and 65 and older. Am J Prev Med 31(1):72-79. https://doi.org/10.1016/j.amepre.2006.03.008

Maglione PJ, Xu J, Chan J (2007) B cells moderate inflammatory progression and enhance bacterial containment upon pulmonary challenge with mycobacterium tuberculosis. J Immunol (Baltimore, Md: 1950) 178(11):7222-7234. doi:17513771

Manoussakis MN, Tzioufas AG, Silis MP, Pange PJ, Goudevenos J, Moutsopoulos HM (1987) High prevalence of anti-cardiolipin and other autoantibodies in a healthy elderly population. Clin Exp Immunol 69(3):557-565. http://www.pubmedcentral.nih.gov/articlerender.fcgi?artid $=1542366 \&$ tool $=$ pmcentrez\&rendertype $=$ abstract

Martens UM, Brass V, Sedlacek L, Pantic M, Exner C, Guo Y, Engelhardt M, Lansdorp PM, Waller CF, Lange W (2002) Telomere maintenance in human B lymphocytes. Br J Haematol 119(3): 810-818. https://doi.org/10.1046/j.1365-2141.2002.03910.x

Martin V, Bryan Wu YC, Kipling D, Dunn-Walters D (2015) Ageing of the B-cell repertoire. Philos Trans R Soc Lond Ser B Biol Sci 370(1676):20140237. https://doi.org/10.1098/rstb.2014.0237

Martin VG, Wu YB, Townsend CL, Lu GH, O’Hare JS, Mozeika A, Coolen AC, Kipling D, Fraternali F, Dunn-Walters DK (2016) Transitional B cells in early human b cell development time to revisit the paradigm? Front Immunol 7:546

Martins G, Calame K (2008) Regulation and functions of blimp-1 in T and B lymphocytes. Annu Rev Immunol 26(1):133-169. https://doi.org/10.1146/annurev.immunol.26.021607.090241

Matias G, Taylor R, Haguinet F, Schuck-Paim C, Lustig R, Shinde V (2014) Estimates of mortality attributable to influenza and RSV in the United States during 1997-2009 by influenza type or subtype, age, cause of death, and risk status. Influenza Other Respir Viruses 8(5):507-515. https://doi.org/10.1111/irv.12258

Mattila PS, Tarkkanen J (1997) Age-associated changes in the cellular composition of the human adenoid. Scand J Immunol 45(4):423-427

Mauri C, Menon M (2015) The expanding family of regulatory B cells. Int Immunol. 27(10):479-86. https://doi.org/10.1093/intimm/dxv038

Mazzoccoli G, Inglese M, De Cata A, Carughi S, Dagostino MP, Marzulli N, Damato M, Grilli M, Giuliani F, Greco A (2011) Neuroendocrine-immune interactions in healthy aging. Geriatr Gerontol Int 11(1):98-106. https://doi.org/10.1111/j.1447-0594.2010.00628.x

McElhaney JE, Kuchel GA, Zhou X, Swain SL, Haynes L (2016) T-cell immunity to influenza in older adults: a pathophysiological framework for development of more effective vaccines. Front Immunol 7(FEB):41. https://doi.org/10.3389/fimmu.2016.00041

McIntosh EDG, Conway P, Willingham J, Hollingsworth R, Lloyd A (2005) Pneumococcal pneumonia in the UK-how herd immunity affects the cost-effectiveness of 7-valent pneumococcal conjugate vaccine (PCV). Vaccine 23(14):1739-1745. https://doi.org/10.1016/j.vaccine. 2004.08.051 
Meffre E, Wardemann H (2008) B-cell tolerance checkpoints in health and autoimmunity. Curr Opin Immunol. 20(6):632-8. https://doi.org/10.1016/j.coi.2008.09.001

Melzer S, Zachariae S, Bocsi J, Engel C, Löffler M, Tárnok A (2015) Reference intervals for leukocyte subsets in adults: results from a population-based study using 10-color flow cytometry. Cytometry Part B 281(April):270-281. https://doi.org/10.1002/cyto.b.21234

Michou L, Teixeira VH, Pierlot C, Lasbleiz S, Bardin T, Dieudé P, Prum B, Cornélis F, Petit-Teixeira E (2008) Associations between genetic factors, tobacco smoking and autoantibodies in familial and sporadic rheumatoid arthritis. Ann Rheum Dis 67(August):466-470. https://doi.org/10.1136/ard.2007.075622

Millett ER, De Stavola BL, Quint JK, Smeeth L, Thomas SL (2015) Risk factors for hospital admission in the 28 days following a community-acquired pneumonia diagnosis in older adults, and their contribution to increasing hospitalisation rates over time: a cohort study. BMJ Open 5(12):e008737. https://doi.org/10.1136/bmjopen-2015-008737

Moir S, Ho J, Malaspina A, Wang W, DiPoto AC, O'Shea MA, Roby G et al (2008) Evidence for HIV-associated B cell exhaustion in a dysfunctional memory B cell compartment in HIVinfected viremic individuals. J Exp Med 205(8):1797-1805. https://doi.org/10.1084/jem.200 72683

Monaghan TM, Robins A, Knox A, Sewell HF, Mahida YR (2013) Circulating antibody and memory B-Cell responses to C. difficile toxins A and B in patients with C. difficile-associated diarrhoea, inflammatory bowel disease and cystic fibrosis. PLoS One 8(9):e74452. https://doi. org/10.1371/journal.pone.0074452

Monath TP, Cetron MS, McCarthy K, Nichols R, Tad Archambault W, Weld L, Bedford P (2005) Yellow fever 17D vaccine safety and immunogenicity in the elderly. Hum Vaccin 1(5):207-214. https://doi.org/10.4161/hv.1.5.2221

Mouquet H, Scheid JF, Zoller MJ, Krogsgaard M, Ott RG, Shukair S, Artyomov MN et al (2010) Polyreactivity increases the apparent affinity of anti-HIV antibodies by heteroligation. Nature 467(7315):591-595. https://doi.org/10.1038/nature09385

Mueller-Ortiz SL, Drouin SM, Wetsel RA (2004) The alternative activation pathway and complement component CS are critical for a protective immune reponse against Pseudomonas aeruginosa in a murine model of pneumonia. Infect Immun 72(5):2899-2906

Naradikian MS, Hao Y, Cancro MP (2016) Age-associated B cells: key mediators of both protective and autoreactive humoral responses. Immunol Rev 269(1):118-129. https://doi.org/10.1111/ imr. 12380

Nelson BH (2010) CD20+ B cells: the other tumor-infiltrating lymphocytes. TL - 185. J Immunol (Baltimore, Md: 1950) 185(9):4977-4982. https://doi.org/10.4049/jimmunol.1001323

NHS Digital (2016) Statistical Publications catalogue [Internet]. http://digital.nhs.uk/search catalogue

Nikolajczyk BS (2010) B cells as under-appreciated mediators of non-auto-immune inflammatory disease. Cytokine. 50(3):234-42. https://doi.org/10.1016/j.cyto.2010.02.022

Nilsson BO, Skogh T, Ernerudh J, Johansson B, Löfgren S, Wikby A, Dahle C (2006) Antinuclear antibodies in the oldest-old women and men. J Autoimmun 27(4):281-288. https://doi.org/ 10.1016/j.jaut.2006.10.002

Norrback KF, Hultdin M, Dahlenborg K, Osterman P, Carlsson R, Roos G (2001) Telomerase regulation and telomere dynamics in germinal centers. Eur J Haematol 67(5-6):309-317. https://doi.org/10.1034/j.1600-0609.2001.00588.x

Odelin MF, Momplot C, Bourlet T, Gonthier R, Aymard M, Pozzetto B (2003) Temporal surveillance of the humoral immunity against influenza vaccine in the elderly over 9 consecutive years. Gerontology 49(4):233-239. https://doi.org/10.1159/000070403

Örtqvist $\AA$, Hedlund J, Burman L-Å, Elbel E, Höfer M, Leinonen M, Lindblad I, Sundelöf B, Kalin M (1998) Randomised trial of 23-valent pneumococcal capsular polysaccharide vaccine in prevention of pneumonia in middle-aged and elderly people. Lancet 351(9100):399-403. https://doi.org/10.1016/S0140-6736(97)07358-3 
Örtqvist Å, Henckaerts I, Hedlund J, Poolman J (2007) Non-response to specific serotypes likely cause for failure to 23-valent pneumococcal polysaccharide vaccine in the elderly. Vaccine 25(13):2445-2450. https://doi.org/10.1016/j.vaccine.2006.09.018

Park CS, Choi YS (2005) How do follicular dendritic cells interact intimately with B cells in the germinal centre? Immunology. https://doi.org/10.1111/j.1365-2567.2004.02075.x

Park S, Nahm MH (2011) Older adults have a low capacity to opsonize pneumococci due to low Igm antibody response to pneumococcal vaccinations. Infect Immun 79(1):314-320. https://doi. org/10.1128/IAI.00768-10

Perl A (2015) MTOR activation Is a biomarker and a central pathway to autoimmune disorders, cancer, obesity, and aging. Ann N Y Acad Sci 1346(1):33-44. https://doi.org/10.1111/nyas. 12756

Peterson EM, de la Maza LM, Brade L et al (1998) Characterization of a neutralizing monoclonal antibody directed at the lipopolysaccharide of Chlamydia pneumoniae. Infect Immun 66(8): $3848-3855$

Pichichero ME, Hall CB, Insel RA (1981) A mucosal antibody response following systemic Haemophilus influenzae type B infection in children. J Clin Invest 67:1482-1489

Pritz T, Lair J, Ban M, Keller M, Weinberger B, Krismer M, Grubeck-Loebenstein B (2015) Plasma cell numbers decrease in bone marrow of old patients. Eur J Immunol 45(3):738-746. https:// doi.org/10.1002/eji.201444878

Puga I, Cols M, Barra CM, He B, Cassis L, Gentile M, Comerma L et al (2011) B cell-helper neutrophils stimulate the diversification and production of immunoglobulin in the marginal zone of the spleen. Nat Immunol 13(2):170-180. https://doi.org/10.1038/ni.2194

Puzianowska-Kuźnicka M, Owczarz M, Wieczorowska-Tobis K, Nadrowski P, Chudek J, Slusarczyk P, Skalska A, Jonas M, Franek E, Mossakowska M (2016) Interleukin-6 and C-reactive protein, successful aging, and mortality: the PolSenior study. Immun Ageing 13:21. https://doi.org/10.1186/s12979-016-0076-x. eCollection 2016. PMID: 27274758

Qin D, Wu J, Vora KA, Ravetch JV, Szakal AK, Manser T, Tew JG (2000) Fc gamma receptor IIB on follicular dendritic cells regulates the B cell recall response. J Immunol (Baltimore, Md: 1950) 164(12):6268-6275. https://doi.org/10.4049/jimmunol.164.12.6268

Radl J (1990) Age-related monoclonal gammapathies: clinical lessons from the aging C57BL mouse. Immunol Today 11(7):234-236. http://www.ncbi.nlm.nih.gov/pubmed/2201308

Ratliff M, Alter S, Frasca D, Blomberg BB, Riley RL (2013) In senescence, age-associated B cells secrete Tnfo and inhibit survival of B-cell precursors. Aging Cell 12(2):303-311. https://doi. org/10.1111/acel.12055

Reber AJ, Kim JH, Biber R, Keipp Talbot H, Coleman LA, Chirkova T, Liaini Gross F et al (2015) Preexisting immunity, more than aging, influences influenza vaccine responses. Open Forum Infect Dis 2(2):ofv052. https://doi.org/10.1093/ofid/ofv052

Rivera A, Chen CC, Ron N et al (2001) Role of B cells as antigen-presenting cells in vivo revisited: antigen-specific B cells are essential for T cell expansion in lymph nodes and for systemic T cell responses to low antigen concentrations. Int Immunol 13(12):1583-1593

Rizzo C, Viboud C, Montomoli E, Simonsen L, Miller MA (2006) Influenza-related mortality in the Italian elderly: no decline associated with increasing vaccination coverage. Vaccine 24(42-43): 6468-6475. https://doi.org/10.1016/j.vaccine.2006.06.052

Rogozin IB, Diaz M (2004) Cutting edge: DGYW/WRCH is a better predictor of mutability at G:C bases in Ig hypermutation than the widely accepted RGYW/WRCY motif and probably reflects a two-step activation-induced cytidine deaminase-triggered process. J Immunol 172(6): $3382-3384$

Rogozin IB, Kolchanov NA (1992) Somatic hypermutagenesis in immunoglobulin genes. II. Influence of neighbouring base sequences on mutagenesis. BBA - Gene Struct Expr 1171(1): 11-18. https://doi.org/10.1016/0167-4781(92)90134-L

Rothstein TL, Quach TD (2015) The human counterpart of mouse B-1 cells. Ann N Y Acad Sci 1362(1):143-152. https://doi.org/10.1111/nyas. 12790

Roukens AH, Soonawala D, Joosten SA, de Visser AW, Jiang X, Dirksen K, de Gruijter M, van Dissel JT, Bredenbeek PJ, Visser LG (2011) Elderly subjects have a delayed antibody response 
and prolonged viraemia following yellow fever vaccination: a prospective controlled cohort study. PLoS One 6(12):e27753. https://doi.org/10.1371/journal.pone.0027753

Rubelt F, Sievert V, Knaust F, Diener C, Lim TS, Skriner K, Klipp E, Reinhardt R, Lehrach H, Konthur Z (2012) Onset of immune senescence defined by unbiased pyrosequencing of human immunoglobulin mRNA repertoires. PLoS One 7(11):e49774. https://doi.org/10.1371/journal. pone. 0049774

Rubins JB, Janoff EN (2001) Pneumococcal disease in the elderly: what is preventing vaccine efficacy? Drugs Aging 18(5):305-311. http://www.ncbi.nlm.nih.gov/pubmed/11392439

Rubtsova K, Rubtsov AV, Cancro MP, Marrack P (2015) Age-associated B cells: a T-Bet-dependent effector with roles in protective and pathogenic immunity. J Immunol 195(5):1933-1937. https://doi.org/10.4049/jimmunol.1501209

Sage PT, Sharpe AH (2016) T follicular regulatory cells. Immunol Rev 271(1):246-259. https://doi. org/10.1111/imr.12411

Saul L, Ilieva KM, Bax HJ, Karagiannis P, Correa I, Rodriguez-Hernandez I, Josephs DH, Tosi I, Egbuniwe IU, Lombardi S, Crescioli S, Hobbs C, Villanova F, Cheung A, Geh JL, Healy C, Harries M, Sanz-Moreno V, Fear DJ, Spicer JF, Lacy KE, Nestle FO, Karagiannis SN (2016) IgG subclass switching and clonal expansion in cutaneous melanoma and normal skin. Sci Rep 6:29736. https://doi.org/10.1038/srep29736

Savage WJ, Bleesing JJ, Douek D, Brown MR, Linton GM, Malech HL, Horwitz ME (2001) Lymphocyte reconstitution following non-myeloablative hematopoietic stem cell transplantation follows two patterns depending on age and donor/recipient Chimerism. Bone Marrow Transplant 28(5):463-471. https://doi.org/10.1038/sj.bmt.1703176

Scarfò L, Ghia P (2016) What does it mean I have a monoclonal B-cell lymphocytosis?: recent insights and new challenges. Semin Oncol 43(2):201-208. https://doi.org/10.1053/j.seminoncol.2016.02.013. Epub 2016 Feb 6. Review

Scheid JF, Mouquet H, Kofer J, Yurasov S, Nussenzweig MC, Wardemann H (2011) Differential regulation of self-reactivity discriminates between $\mathrm{IgG}+$ human circulating memory B cells and bone marrow plasma cells. Proc Natl Acad Sci USA 108(44):18044-18048. https://doi.org/ 10.1073/pnas.1113395108. 1113395108 [pii]

Schwartz M, Zhang Y, Rosenblatt JD (2016) B cell regulation of the anti-tumor response and role in carcinogenesis. J Immunother Cancer 4:40. https://doi.org/10.1186/s40425-016-0145-x

Seki M, Yanagihara K, Higashiyama Y, Fukuda Y, Kaneko Y, Ohno H, Miyazaki Y et al (2004) Immunokinetics in severe pneumonia due to influenza virus and bacteria coinfection in mice. Eur Respir J 24(1):143-149. https://doi.org/10.1183/09031936.04.00126103

Shi Y, Yamazaki T, Okubo Y, Uehara Y, Sugane K, Agematsu K (2005) Regulation of aged humoral immune defense against pneumococcal bacteria by IgM memory B cell. J Immunol (Baltimore, Md: 1950) 175(5):3262-3267. https://doi.org/10.4049/jimmunol.175.5.3262

Simberkoff MS, Cross AP, Al-Ibrahim M, Baltch AL, Geiseler PJ, Nadler J, Richmond AS et al (1986) Efficacy of pneumococcal vaccine in high-risk patients. Results of a veterans administration cooperative study. N Engl J Med 315(21):1318-1327. https://doi.org/10.1056/NEJM 198611203152104

Simonsen L, Reichert TA, Viboud C, Blackwelder WC, Taylor RJ, Miller MA (2005) Impact of influenza vaccination on seasonal mortality in the US elderly population. Arch Intern Med 165(3):265-272. https://doi.org/10.1001/archinte.165.3.265

Smith TJ, Chase ES, Schmidt TJ et al (1996) Neutralizing antibody to human rhinovirus 14 penetrates the receptor-binding canyon. Nature 383(6598):350-354

Son NH, Murray S, Yanovski J, Hodes RJ, Weng N (2000) Lineage-specific telomere shortening and unaltered capacity for telomerase expression in human $\mathrm{T}$ and $\mathrm{B}$ lymphocytes with age. J Immunol (Baltimore, Md: 1950) 165(3):1191-1196. doi:ji_v165n3p1191 [pii]

Spencer J, Dunn M, Dunn-Walters DK (1999) Characteristics of sequences around individual nucleotide substitutions in $\{\mathrm{IgVH}\}$ genes suggest different $\{\mathrm{GC}\}$ and $\{\mathrm{AT}\}$ mutators. J Immunol 162(11):6596-6601 
Suzuki K, Inoue S, Kametani Y, Komori Y, Chiba S, Sato T, Inokuchi S, Ogura S (2016) Reduced immunocompetent B cells and increased secondary infection in elderly patients with severe sepsis. Shock 46:270. [Epub ahead of print]

Szakal AK, Kosco MH, Tew JG (1988) A novel in vivo follicular dendritic cell-dependent iccosome-mediated mechanism for delivery of antigen to antigen-processing cells. J Immunol 140(2):341-353. http://www.ncbi.nlm.nih.gov/entrez/query.fcgi?cmd=Retrieve\&db=PubMed $\&$ dopt $=$ Citation\&list_uids $=3257233$

Taylor RC (2016) Aging and the UPR(ER). Brain Res. 1648(Pt B):588-593. https://doi.org/ 10.1016/j.brainres.2016.04.017

Tellier J, Shi W, Minnich M, Liao Y, Crawford S, Smyth GK, Kallies A, Busslinger M, Nutt SL (2016) Blimp-1 controls plasma cell function through the regulation of immunoglobulin secretion and the unfolded protein response. Nat Immunol 17(3):323-330. https://doi.org/ 10.1038/ni.3348

Tete SM, Kipling D, Westra J, de Haan A, Bijl M, Dunn-Walters DK, Sahota SS, Bos NA (2015) Monoclonal paraprotein influences baseline B-cell repertoire diversity and perturbates influenza vaccination-induced B-cell response. Exp Hematol 43(6):439-447. https://doi.org/10.1016/j. exphem.2015.02.005

Tew JG, Wu J, Qin D, Helm S, Burton GF, Szakal AK (1997) Follicular dendritic cells and presentation of antigen and costimulatory signals to B cells. Immunol Rev 156:39-52. https://doi.org/10.1111/j.1600-065X.1997.tb00957.x

Thomas RE, Lorenzetti DL, Spragins W, Jackson D, Williamson T (2012) The safety of yellow fever vaccine 17D or 17DD in children, pregnant women, HIV+ individuals, and older persons: systematic review. Am J Trop Med Hyg 86(2):359-372. https://doi.org/10.4269/ajtmh. 2012.11-0525

Thompson WW, Shay DK, Weintraub E, Brammer L, Cox N, Anderson LJ, Fukuda K (2003) Mortality associated with influenza and respiratory syncytial virus in the United States. JAMA 289(2):179-186. https://doi.org/10.1001/jama.289.2.179

Torchilin VP, Iakoubov LZ, Estrov Z (2001) Antinuclear autoantibodies as potential antineoplastic agents. Trends Immunol 22(8):424-427

Torres M, May R, Scharff MD, Casadevall A (2005) Variable-region-identical antibodies differing in isotype demonstrate differences in fine specificity and idiotype. J Immunol 174(4): 2132-2142. https://doi.org/10.4049/jimmunol.174.4.2132

Trinchieri A, Braceschi L, Tiranti D et al (1990) Secretory immunoglobulin A and inhibitory activity of bacterial adherence to epithelial cells in urine from patients with urinary tract infections. Urol Res 18(5):305-308

van Beek AA, Hugenholtz F, Meijer B, Sovran B, Perdijk O, Vermeij WP, Brandt RM, Barnhoorn S, Hoeijmakers JH, de Vos P, Leenen PJ, Hendriks RW, Savelkoul HF (2016) Tryptophan restriction arrests B cell development and enhances microbial diversity in WT and prematurely aging Ercc1-/ $\Delta 7$ mice. J Leukoc Biol. 101(4):811-821. pii: jlb.1HI0216-062RR.

van der Geest KSM, Lorencetti PG, Abdulahad WH, Horst G, Huitema M, Roozendaal C, Kroesen BJ, Brouwer E, Boots AMH (2016) Aging-dependent decline of IL-10 producing B cells coincides with production of antinuclear antibodies but not rheumatoid factors. Exp Gerontol 75:24-29. https://doi.org/10.1016/j.exger.2015.12.009

van der Sluijs KF, van Elden LJR, Nijhuis M, Schuurman R, Pater JM, Florquin S, Goldman M, Jansen HM, Lutter R, van der Poll T (2004) IL-10 Is an important mediator of the enhanced susceptibility to pneumococcal pneumonia after influenza infection. J Immunol (Baltimore, Md: 1950) 172(12):7603-7609. https://doi.org/10.4049/jimmunol.172.12.7603

Van Zelm MC, Bartol SJW, Driessen GJ, Mascart F, Reisli I, Franco JL, Wolska-Kusnierz B et al (2014) Human CD19 and CD40L deficiencies impair antibody selection and differentially affect somatic hypermutation. J Allergy Clin Immunol 134(1):135. https://doi.org/10.1016/j.jaci. 2013.11.015 
Wang L, Benedito R, Gabriele Bixel M, Zeuschner D, Stehling M, Sävendahl L, Haigh JJ et al (2013) Identification of a clonally expanding haematopoietic compartment in bone marrow. EMBO J 32(2):219-230. https://doi.org/10.1038/emboj.2012.308

Wang C, Liu Y, Xu LT, Jackson KJL, Roskin KM, Pham TD, Laserson J et al (2014) Effects of aging, cytomegalovirus infection, and EBV infection on human B cell repertoires. J Immunol 192(2):603-611. https://doi.org/10.4049/jimmunol.1301384

Watts RA, Lane SE, Bentham G, Scott DGI (2000) Epidemiology of systemic vasculitis: a ten-year study in the United Kingdom. Arthritis Rheum 43(2):414-419. https://doi.org/10.1002/15290131(200002)43:2<414::AID-ANR23>3.0.CO;2-0

Wei C, Anolik J, Cappione A, Zheng B, Pugh-Bernard A, Brooks J, Lee E-H, Milner ECB, Sanz I (2007) A new population of cells lacking expression of CD27 represents a notable component of the B cell memory compartment in systemic lupus erythematosus. J Immunol 178(10): 6624-6633. https://doi.org/10.4049/jimmunol.178.10.6624

Weil-Olivier C, van der Linden M, de Schutter I, Dagan R, Mantovani L (2012) Prevention of pneumococcal diseases in the post-seven valent vaccine era: a European perspective. BMC Infect Dis 12(1):207. https://doi.org/10.1186/1471-2334-12-207

Weinberger B, Schirmer M, Gothe RM, Siebert U, Fuchs D, Grubeck-Loebenstein B (2013) Recall responses to tetanus and diphtheria vaccination are frequently insufficient in elderly persons. PLoS One 8(12):e82967. https://doi.org/10.1371/journal.pone.0082967

Weng NP (2008) Telomere and adaptive immunity. Mech Ageing Dev 129(1-2):60-66. https://doi. org/10.1016/j.mad.2007.11.005

Whitaker JA, Shanafelt TD, Poland GA, Kay NE (2014) Room for improvement: immunizations for patients with monoclonal B-cell lymphocytosis or chronic lymphocytic leukemia. Clin Adv Hematol Oncol 12(7):440-450

Wistuba-Hamprecht K, Haehnel K, Janssen N, Demuth I, Pawelec G (2015) Peripheral blood T-cell signatures from high-resolution immune phenotyping of $\Gamma \delta$ and $\mathrm{A} \beta$ T-cells in younger and older subjects in the Berlin aging study II. Immun Ageing 12:1-12. https://doi.org/10.1186/s12979015-0052-x

Wu X, Amos CI, Zhu Y, Zhao H, Grossman BH, Shay JW, Luo S, Hong WK, Spitz MR (2003) Telomere dysfunction: a potential cancer predisposition factor. J Natl Cancer Inst 95(16): 1211-1218. https://doi.org/10.1093/jnci/djg011

Wu Y-CB, Kipling D, Dunn-Walters DK (2011) The relationship between CD27 negative and positive B cell populations in human peripheral blood. Front Immunol 2(December):1-12. https://doi.org/10.3389/fimmu.2011.00081

Wu Y-CB, Kipling D, Dunn-Walters DK (2012) Age-related changes in human peripheral blood IGH repertoire following vaccination. Front Immunol 3(July):193. https://doi.org/10.3389/ fimmu.2012.00193

Xavier RM, Yamauchi Y, Nakamura M, Tanigawa Y, Ishikura H, Tsunematsu T, Kobayashi S (1995) Antinuclear antibodies in healthy aging people: a prospective study. Mech Ageing Dev 78(2):145-154. https://doi.org/10.1016/0047-6374(94)01532-Q

Yoshida K, van den Berg TK, Dijkstra CD (1993) Two functionally different follicular dendritic cells in secondary lymphoid follicles of mouse spleen, as revealed by CR1/2 and FcR gamma II-mediated immune-complex trapping. Immunology 80(1):34-39. http://www.pubmedcentral. nih.gov/articlerender.fcgi?artid $=1422113 \&$ tool $=$ pmcentrez\&rendertype $=$ abstract

Zhang Y, Garcia-Ibanez L, Toellner KM (2016a) Regulation of germinal center B-cell differentiation. Immunol Rev. https://doi.org/10.1111/imr.12396

Zhang H, Puleston DJ, Simon AK (2016b) Autophagy and immune senescence. Trends Mol Med. https://doi.org/10.1016/j.molmed.2016.06.001. pii: S1471-4914(16)30049-1. [Epub ahead of print] Review

Zhong X, Yang H, Guo ZF et al (2005) B-cell responses in patients who have recovered from severe acute respiratory syndrome target a dominant site in the S2 domain of the surface glycoprotein. J Virol 79(6):3401-3408 